\title{
A second note on the geographical differentiation of Amphisbaena fuliginosa L., 1758 (Squamata, Amphisbaenidae), with a consideration of the forest refuge model of speciation
}

\author{
PAUlO EMilio VANZOLINI* \\ Museu de Zoologia da Universidade de São Paulo, Caixa Postal 42694, 04299-970 São Paulo, SP
}

Manuscript received on April 14, 2002; accepted for publication on September 9, 2002.

\begin{abstract}
The geographical differentiation of Amphisbaena fuliginosa L. is studied with basis on 220 specimens from 99 definite and 2 generic localities, ranging from Panamá to Puno in Peru and Goiás in Brasil. The pattern found is considered to support Vanzolini's 1951 scheme of five subspecies, defined by color pattern and by four meristic characters, and differentiated in consequence of Quaternary paleoecological events. Recent developments relating to models of differentiation in Quaternary tropical South America are briefly considered.
\end{abstract}

Key words: subspecies, paleoclimates, Amphisbaena, refuge model.

\section{INTRODUCTION}

I published in 1951 a study of the geographic variation of Amphisbaena fuliginosa Linnaeus, 1758, concluding that five subspecies could be recognized, based mainly on color pattern, but with substantial support from scale counts. The paper was written in the flush and heat of the Mayrian paradigm (Mayr 1942): if two taxa are similar and allopatric, they should be considered as geographical races or subspecies. I have since come to question the unqualified application of the paradigm. The concept of subspecies involves more than likeness and allopatry; it entails too the presence of broad areas of morphological stability connected by relatively narrow belts of integradation (Vanzolini and Williams 1970). Additionally, I came to worry about the statistical tools: the methods then available in textbooks within my reach were not ideally suited to the

\footnotetext{
* Member of Academia Brasileira de Ciências

E-mail: vanzo@usp.br
}

study of geographical differentiation.

This Museum has recently received a fine sample of A. fuliginosa from an entirely unexpected area, not forested, as were all represented before, but sited in the core of the domain of the cerrados, eminently open formations (Ab'Saber 1977, Projeto Radambrasil 1981). The need to place in context this sample, so distant ecologically and geographically from those hitherto known, led me to re-examine the problem, including materials gathered since 1951, as well as better, if still elementary, statistical methods.

\section{MATERIALS AND METHODS}

\section{SPECIMENS}

I used in the present analysis in part the data of the 1951 paper, in part specimens collected since. The former were 135 specimens from 63 definite localities and 5 from generic ones ("Surinam" and 
TABLE I

Amphisbaena fuliginosa, body annuli, statistics of the distributions of frequencies.

\begin{tabular}{l|c|c|c|c|c}
\hline Sample & $\mathrm{N}$ & $\mathrm{R}$ & $\mathrm{m}$ & $\mathrm{s}$ & $\mathrm{V}$ \\
\hline Oriximiná & 8 & $191-199$ & $194.8 \pm 1.10$ & 3.1 & 1.6 \\
Roraima & 10 & $183-201$ & $194.9 \pm 2.22$ & 7.0 & 3.6 \\
Serra da Mesa & 13 & $189-202$ & $193.5 \pm 1.51$ & 5.5 & 2.8 \\
Rondonia & 9 & $184-205$ & $195.4 \pm 2.64$ & 7.9 & 4.1 \\
Colombia & 10 & $190-205$ & $197.7 \pm 1.32$ & 4.2 & 2.1 \\
Panamá & 10 & $195-202$ & $198.4 \pm 0.81$ & 2.5 & 1.3 \\
Ecuador West & 14 & $190-205$ & $198.5 \pm 1.12$ & 4.2 & 2.1 \\
Aripuanã & 6 & $195-206$ & $200.3 \pm 1.69$ & 4.1 & 1.7 \\
Ecuador East & 11 & $196-209$ & $202.1 \pm 1.25$ & 4.2 & 2.1 \\
Surinam & 10 & $193-216$ & $203.5 \pm 2.06$ & 6.5 & 3.2 \\
Pará & 9 & $196-214$ & $204.8 \pm 1.89$ & 5.7 & 2.8 \\
Trinidad & 17 & $202-212$ & $206.2 \pm 0.68$ & 2.8 & 1.4 \\
Guyana & 10 & $199-218$ & $206.8 \pm 1.71$ & 5.4 & 2.6 \\
Iquitos & 18 & $204-213$ & $207.8 \pm 0.59$ & 2.5 & 0.6 \\
Ucayali & 11 & $204-215$ & $210.5 \pm 0.95$ & 3.1 & 1.5 \\
Manaus & 18 & $206-220$ & $212.8 \pm 0.94$ & 4.0 & 1.9 \\
\hline \multicolumn{5}{|r}{}
\end{tabular}

TABLE II

Amphisbaena fuliginosa, body annuli, Tukey's test.

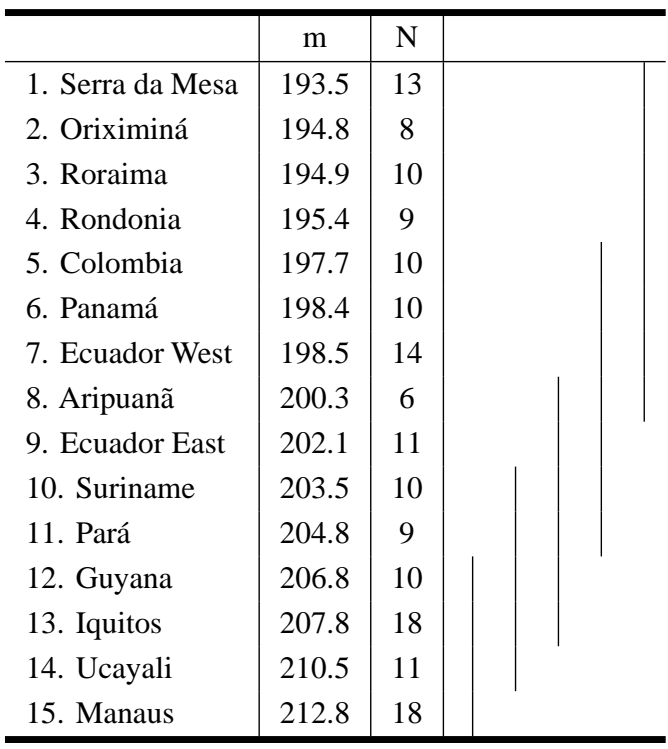

“'Trinidad"). The latter were 80 specimens from 37 definite localities. In all, 220 specimens, only 2 localities present in both samples. The materials are listed in the Appendix.

\section{Scale Counts and Measurements}

I have at hand not many, but enough of the 1951 specimens to be sure that measurements and scale counts, taken so far apart in time, are fully compatible.

Four scale counts and two body proportions are here studied:

Body annuli, counted from the first complete post-occipital annulus to the one in front of the row of preanal pores. The annuli of A. fuliginosa usually show many irregularities, with partial splits and fusions. Differences due to these causes between successive counts seldom reached more than 2-3 annuli, i.e., $1 \%$ of the count. This, combined with broad range and small variability, makes the character, to me, very important in taxonomy. I adopted the first count of each specimen, checked the extremes of each distribution, and did some additional spot-checking.

Tail annuli, counted ventrally, from the first complete post-anal annulus to the tip of the tail, the terminal conical segment included.

Segments to a midbody annulus were, due to 


\section{TABLE III}

Amphisbaena fuliginosa, body annuli, southern transect.

\begin{tabular}{|c|c|c|c|c|c|c|}
\hline Annuli & Ucayali & Acre & Rondonia & Aripuanã & Sa. da Mesa & Sta. Maria \\
\hline 184 & & & 1 & & & \\
\hline 185 & & & 1 & & & \\
\hline 186 & & & - & & & \\
\hline 187 & & & - & & & \\
\hline 188 & & & - & & & \\
\hline 189 & & & 1 & & 1 & \\
\hline 190 & & & - & & 1 & \\
\hline 191 & & & - & & & \\
\hline 192 & & & - & & 2 & \\
\hline 193 & & & - & & 1 & \\
\hline 194 & & & - & & 1 & \\
\hline 195 & & & 1 & 1 & 1 & \\
\hline 196 & & & 1 & - & 2 & \\
\hline 197 & & & - & - & - & 1 \\
\hline 198 & & 1 & - & 2 & 1 & - \\
\hline 199 & & - & 1 & - & 1 & - \\
\hline 200 & & - & - & - & 1 & - \\
\hline 201 & & - & - & 1 & - & - \\
\hline 202 & & - & 1 & - & 1 & 1 \\
\hline 203 & & - & - & - & & - \\
\hline 204 & 1 & - & 1 & 1 & & - \\
\hline 205 & 1 & - & 1 & - & & - \\
\hline 206 & - & - & & 1 & & 1 \\
\hline 207 & - & - & & & & \\
\hline 208 & 2 & - & & & & \\
\hline 209 & - & 1 & & & & \\
\hline 210 & 2 & & & & & \\
\hline 211 & 3 & & & & & \\
\hline 212 & 1 & & & & & \\
\hline 213 & - & & & & & \\
\hline 214 & - & & & & & \\
\hline 215 & 2 & & & & & \\
\hline Sum & 12 & 2 & 9 & 6 & 13 & 3 \\
\hline
\end{tabular}


TABLE IV

Amphisbaena fuliginosa, body annuli, West-East transect.

\begin{tabular}{|c|c|c|c|c|c|c|c|c|c|c|}
\hline Annuli & $\begin{array}{c}\text { W } \\
\text { Ecuador }\end{array}$ & $\begin{array}{c}\mathrm{E} \\
\text { Ecuador }\end{array}$ & Iquitos & Leticia & $\begin{array}{l}\text { Taba- } \\
\text { tinga }\end{array}$ & Berurí & Manaus & $\begin{array}{l}\text { Itapi- } \\
\text { ranga }\end{array}$ & $\begin{array}{l}\text { Orixi- } \\
\text { miná }\end{array}$ & Pará \\
\hline 190 & 1 & & & & & & & & & \\
\hline 191 & - & & & & & & & & 2 & \\
\hline 192 & - & & & & & & & & 1 & \\
\hline 193 & 1 & & & & & & & & - & \\
\hline 194 & - & & & & & & & & - & \\
\hline 195 & - & & & & & & & & 1 & \\
\hline 196 & 2 & 1 & & & & & & & 2 & 1 \\
\hline 197 & 2 & 1 & & & & & & & - & 1 \\
\hline 198 & 1 & 1 & & & & & & & 1 & - \\
\hline 199 & 2 & - & & & & & & & 1 & - \\
\hline 200 & 1 & 2 & & & & & & & & - \\
\hline 201 & - & - & & & & & & & & - \\
\hline 202 & 1 & 3 & & & & & & & & 1 \\
\hline 203 & 1 & - & & & & & & & & - \\
\hline 204 & 1 & - & 2 & & & & & & & - \\
\hline 205 & 1 & 1 & 2 & & & & & & & 1 \\
\hline 206 & & - & 3 & & & & 1 & & & 1 \\
\hline 207 & & 1 & 1 & 1 & & & 2 & & & 1 \\
\hline 208 & & - & 3 & - & 1 & & - & & & 2 \\
\hline 209 & & 1 & 2 & - & & & - & & & - \\
\hline 210 & & & 3 & - & & & 1 & & & - \\
\hline 211 & & & 1 & - & & & 1 & & & - \\
\hline 212 & & & - & - & & 1 & 4 & & & - \\
\hline 213 & & & 1 & - & & & 2 & & & - \\
\hline 214 & & & & 1 & & & 2 & & & 1 \\
\hline 215 & & & & - & & & 2 & & & \\
\hline 216 & & & & - & & & - & & & \\
\hline 217 & & & & - & & & - & & & \\
\hline 218 & & & & - & & & - & & & \\
\hline 219 & & & & - & & & 2 & & & \\
\hline 220 & & & & - & & & 1 & & & \\
\hline 221 & & & & 1 & & & & & & \\
\hline 222 & & & & & & & & & & \\
\hline 223 & & & & & & & & & & \\
\hline 224 & & & & & & & & 1 & & \\
\hline Sum & 14 & 11 & 18 & 3 & 1 & 1 & 18 & 1 & 8 & 9 \\
\hline
\end{tabular}




\section{TABLE V}

Amphisbaena fuliginosa, body annuli, Manaus-Colombia transect.

\begin{tabular}{|c|c|c|c|c|c|c|}
\hline Annuli & Colombia & Villavicencio & Cucuí & Vista Alegre & Balbina & Manaus \\
\hline 190 & 1 & & & & & \\
\hline 191 & - & & & & & \\
\hline 192 & - & & & & & \\
\hline 193 & - & & & & & \\
\hline 194 & - & & & & & \\
\hline 195 & 1 & & & & & \\
\hline 196 & 3 & & & & & \\
\hline 197 & 1 & & & & & \\
\hline 198 & - & & & & & \\
\hline 199 & - & 1 & & & & \\
\hline 200 & 1 & - & & & & \\
\hline 201 & 2 & 1 & & & & \\
\hline 202 & - & - & & 1 & & \\
\hline 203 & - & - & & & & \\
\hline 204 & - & - & & & & \\
\hline 205 & 1 & - & & & & \\
\hline 206 & & 1 & & & & 1 \\
\hline 207 & 1 & & & & & 2 \\
\hline 208 & & 1 & 1 & & & - \\
\hline 209 & & & - & & & - \\
\hline 210 & & & - & & 1 & 1 \\
\hline 211 & & & - & & - & 1 \\
\hline 212 & & & & & - & 4 \\
\hline 213 & & & - & & - & 2 \\
\hline 214 & & & 1 & & 2 & 2 \\
\hline 215 & & & & & & 2 \\
\hline 216 & & & & & & - \\
\hline 217 & & & & & & - \\
\hline 218 & & & & & & - \\
\hline 219 & & & & & & 2 \\
\hline 220 & & & & & & 2 \\
\hline Sum & 10 & 5 & 2 & 1 & 3 & 19 \\
\hline
\end{tabular}


TABLE VI

Amphisbaena fuliginosa, tail annuli, statistics of the distributions of frequencies.

\begin{tabular}{l|c|c|c|c|c}
\hline Sample & $\mathrm{N}$ & $\mathrm{R}$ & $\mathrm{m}$ & $\mathrm{s}$ & $\mathrm{V}$ \\
\hline Pará & 8 & $19-23$ & $21.3 \pm 0.53$ & 1.5 & 7.0 \\
Oriximiná & 6 & $20-23$ & $21.5 \pm 0.43$ & 1.1 & 4.9 \\
Rondonia & 7 & $23-24$ & $23.6 \pm 0.20$ & 0.5 & 2.3 \\
Roraima & 9 & $23-26$ & $24.3 \pm 0.33$ & 1.0 & 4.1 \\
Aripuanã & 5 & $24-25$ & $24.4 \pm 0.24$ & 0.5 & 2.2 \\
Panamá & 5 & $23-27$ & $24.4 \pm 0.68$ & 1.5 & 6.2 \\
Manaus & 14 & $22-26$ & $24.6 \pm 0.33$ & 1.2 & 4.9 \\
Colombia & 9 & $23-27$ & $24.7 \pm 0.41$ & 1.2 & 5.0 \\
Ecuador West & 12 & $23-29$ & $24.9 \pm 0.68$ & 2.4 & 9.4 \\
Serra da Mesa & 8 & $24-27$ & $25.0 \pm 0.46$ & 1.3 & 5.2 \\
Guyana & 9 & $24-29$ & $25.4 \pm 0.60$ & 1.7 & 6.6 \\
Trinidad & 15 & $24-27$ & $25.6 \pm 0.29$ & 1.1 & 4.4 \\
Suriname & 7 & $25-27$ & $25.9 \pm 0.34$ & 0.9 & 3.5 \\
Ecuador East & 5 & $26-27$ & $26.6 \pm 0.24$ & 0.5 & 2.1 \\
Ucayali & 11 & $26-29$ & $27.9 \pm 0.34$ & 1.1 & 4.1 \\
Iquitos & 16 & $26-30$ & $28.4 \pm 0.33$ & 1.3 & 4.6 \\
\hline
\end{tabular}

TABLE VII

Amphisbaena fuliginosa, tail annuli, Tukey's test.

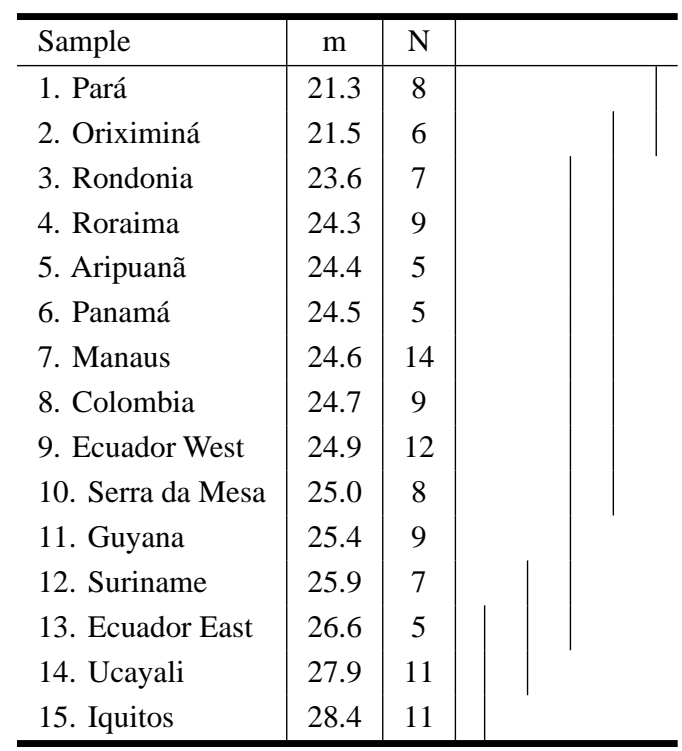

irregularities in the annuli, counted on several adjacent annuli, sited roughly at midbody, and a mode adopted.

Preanal pores.
Two measurements can be meaningfully taken in amphisbaenids, tail length and head width, both proxies for attenuation/elongation of the body, essential information in the case of subterranean limbless animals (Vanzolini 1991).

Tail length was measured ventrally, from the edge of the post-anal semicircle to the tip of the tail.

Head width was measured at the widest point, with calipers, to the nearest millimeter. I see no point in looking for more precision; nobody can go back to a measuring point in a soft-bodied animal within one tenth of a millimeter. Ideally, given the cylindrical shape of amphisbaenids, head width should be regressed on total (body plus tail) length, but there were simply not enough intact tails, and I have had to use body length as the independent variable. Anyway, this turned out to be an uninformative character (Table XXI), and was abandoned.

\section{Statistics}

I used, for the scale counts, the usual descriptive statistics: number of specimens, range, mean and its standard deviation, sample standard deviation and 
TABLE VIII

Amphisbaena fuliginosa, tail annuli, southern transect.

\begin{tabular}{c|c|c|c|c|c|c}
\hline Annuli & Ucayali & Acre & Rondonia & Aripuanã & Serra da Mesa & Santa Maria \\
\hline 23 & & 1 & 3 & & & \\
24 & & & 4 & 3 & 2 & 1 \\
25 & & & & 2 & 2 & - \\
26 & 2 & & & & 3 & - \\
27 & 1 & & & & 1 & - \\
28 & 3 & & & & & 1 \\
29 & 1 & 1 & 7 & 5 & & 2 \\
Sum & 7 & 1 & 14 & 10 & 8 & 3 \\
\hline
\end{tabular}

TABLE IX

Amphisbaena fuliginosa, tail annuli, West-East transect.

\begin{tabular}{|c|c|c|c|c|c|c|c|c|c|}
\hline Annuli & $\begin{array}{c}\mathrm{W} \\
\text { Ecuador }\end{array}$ & $\begin{array}{c}\text { E } \\
\text { Ecuador }\end{array}$ & Iquitos & Leticia & Berurí & Manaus & Itapiranga & Oriximiná & Pará \\
\hline 19 & & & & & & & & & 1 \\
\hline 20 & & & & & & & & & 2 \\
\hline 21 & & & & & & & & 2 & \\
\hline 22 & & & & & & 1 & & 2 & 2 \\
\hline 23 & 2 & & & & & 1 & & 1 & 2 \\
\hline 24 & - & & & & 1 & 3 & 1 & & \\
\hline 25 & 2 & & 3 & 1 & & 5 & & & \\
\hline 26 & 2 & 2 & - & 1 & & 3 & & & \\
\hline 27 & 1 & 3 & 3 & & & - & & & \\
\hline 28 & 1 & 1 & 7 & & & 1 & & & \\
\hline 29 & 2 & & 3 & & & & & & \\
\hline 30 & & & & & & & & & \\
\hline Sum & 10 & 6 & 16 & 2 & 1 & 14 & 1 & 6 & 8 \\
\hline
\end{tabular}

coefficient of variation.

For multiple comparisons I performed analyses of variance, followed by Tukey's test for means. I checked Tukey's test against Kramer's (1956, as modified by Duncan 1957); there were no disagreements. I cite here only Tukey's test, because it is the more widely known.

For the body proportions I first decided on the anamorphosis to be used (all regressions turned out to be linear, with excellent fits) and compared the regressions by analysis of covariance and Tukey's tests for the slope and intercept.

In all cases I tested initially for the presence of sexual differences, based on the 1951 materials. I did not sex the new materials, since the preliminary analysis showed no dimorphism and also because sexing amphisbaenids demands dissection of the base of the tail, which greatly increases the chances of breakage at the autotomy level.

All statistical methods used can be found in 


\section{TABLE X}

Amphisbaena fuliginosa, segments to a midbody annulus, statistics of the distributions of frequencies.

\begin{tabular}{l|c|c|c|c|c}
\hline Sample & $\mathrm{N}$ & $\mathrm{R}$ & $\mathrm{m}$ & $\mathrm{s}$ & $\mathrm{V}$ \\
\hline Ucayali & 12 & $38-44$ & $41.8 \pm 0.63$ & 2.2 & 5.2 \\
Ecuador East & 10 & $40-44$ & $42.8 \pm 0.44$ & 1.4 & 3.3 \\
Iquitos & 18 & $42-46$ & $43.9 \pm 0.20$ & 0.8 & 1.9 \\
Ecuador West & 14 & $42-46$ & $44.1 \pm 0.33$ & 1.2 & 2.8 \\
Trinidad & 17 & $40-50$ & $44.2 \pm 0.57$ & 2.3 & 5.3 \\
Colombia & 10 & $40-50$ & $44.6 \pm 1.08$ & 3.4 & 7.6 \\
Rondonia & 9 & $40-46$ & $44.7 \pm 0.67$ & 2.0 & 4.5 \\
Oriximiná & 8 & $42-48$ & $44.8 \pm 0.65$ & 1.8 & 4.1 \\
Guyana & 10 & $40-50$ & $45.6 \pm 1.02$ & 3.2 & 7.1 \\
Panamá & 10 & $44-48$ & $45.8 \pm 0.55$ & 1.8 & 3.8 \\
Aripuanã & 6 & $44-52$ & $46.7 \pm 1.12$ & 2.7 & 5.9 \\
Manaus & 19 & $44-50$ & $47.1 \pm 0.44$ & 1.9 & 4.1 \\
Pará & 10 & $46-52$ & $48.4 \pm 0.58$ & 1.8 & 3.8 \\
Suriname & 9 & $46-54$ & $49.1 \pm 1.01$ & 3.0 & 6.2 \\
Roraima & 9 & $46-52$ & $49.8 \pm 0.40$ & 1.2 & 2.4 \\
Serra da Mesa & 13 & $48-52$ & $50.9 \pm 0.43$ & 1.6 & 3.1 \\
\hline
\end{tabular}

elementary texts, such as Dixon and Massey (1983), Vanzolini (1993a) or Zar (1999).

Conventions used in the tables of frequency distributions are: $\mathrm{N}$, individuals in sample; $\mathrm{R}$, range of the variable; $\mathrm{m}$, mean \pm its standard deviation; $\mathrm{s}$, sample standard deviation; $\mathrm{V}$, coefficient of variation.

In the regression tables: $\mathrm{N}$, individuals in sample; $\mathrm{R}(\mathrm{x}), \mathrm{R}(\mathrm{y})$, ranges of the variables; $\mathrm{b}$, coefficient of regression (slope) \pm its standard deviation; a, regression constant (intercept) \pm its standard deviation; F, Fisher's variance ratio, for the evaluation of the significance of the regression; $\mathrm{r}^{2}$, coefficient of determination.

In all tables and in the text: ns, not significant at the $5 \%$ level; *, significant at the $5 \%$ level; **, significant at the $1 \%$ level; $* * *$, significant at the $0.1 \%$ level.

\section{TACTICS}

The ideal basic sample in the study of geographic differentiation is a good series of specimens from a single well-defined locality. The concept of a " $\operatorname{good}$ series" depends on the variability of the character and on the number of specimens It should be kept in mind that, at the 5\% level of significance, $t$ for 5 degrees of freedom is 2.571; for 10 degrees, 2.228; for 15, 2.131; for 30, 2.042; and, for infinity, 1.960 . Not much gain after 15 . In the case of characters with little variability and sharp differences (the only ones of real practical interest), samples with 6 or 8 specimens usually turn out quite useful.

For the present study I had the following samples from single localities: Manaus (20 specimens), Iquitos (18), Oriximiná (8), Serra da Mesa (12) and Aripuanã (6).

The next choice is to group localities reasonably close together geographically and ecologically homogeneous. This is obviously a subjective pro- 
TABLE XI

Amphisbaena fuliginosa, segments to a midbody annuli, Tukey's test.

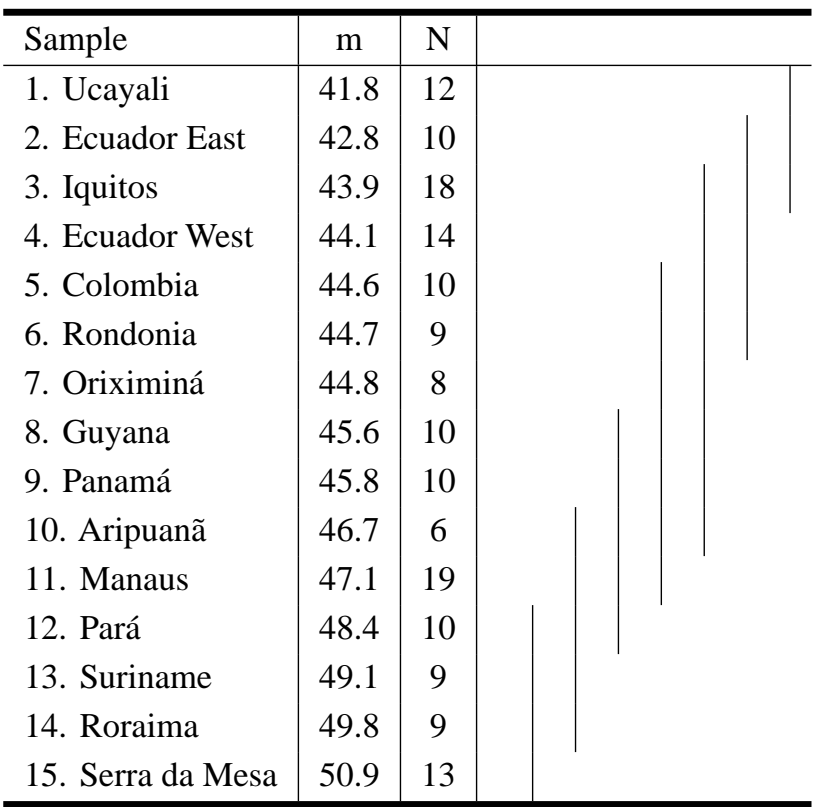

TABLE XII

Amphisbaena fuliginosa, segments to a midbody annulus, Manaus-Colombia transect.

\begin{tabular}{c|c|c|c|c|c|c}
\hline Segments & Colombia & Villavicencio & Cucuí & Vista Alegre & Balbina & Manaus \\
\hline 40 & 1 & & & & & \\
41 & - & & & & & \\
42 & 4 & & 1 & & & \\
43 & - & & - & & & \\
44 & 1 & & 1 & & & 3 \\
45 & - & & & & & - \\
46 & 2 & & & 1 & & 6 \\
47 & - & & & & & - \\
48 & 1 & 1 & & & 2 & 8 \\
49 & - & - & & & - & - \\
50 & 1 & 3 & & & - & 3 \\
51 & & - & & & 1 & \\
52 & & 1 & & & & \\
Sum & 10 & 5 & 2 & 1 & & \\
\hline
\end{tabular}

cedure. Its adequacy can be tested by comparing the coefficients of variation of the grouped samples with those of the single-locality ones e.g, Tables I, VI, X and XIV). My grouped samples are Colom- bia, Ecuador West and East, Guyana, Panamá, Pará, Roraima, Surinam, Trinidad and Ucayali.

Localities represented by one or very few specimens may be used in two ways, depending on the ge- 


\section{TABLE XIII}

Amphisbaena fuliginosa, segments to a midbody annuli, West-East transect.

\begin{tabular}{|c|c|c|c|c|c|c|c|c|c|}
\hline Segments & $\begin{array}{c}\text { W } \\
\text { Ecuador }\end{array}$ & $\begin{array}{c}\text { E } \\
\text { Ecuador }\end{array}$ & Iquitos & Leticia & Berurí & Manaus & $\begin{array}{l}\text { Itapi- } \\
\text { ranga }\end{array}$ & $\begin{array}{l}\text { Orixi- } \\
\text { miná }\end{array}$ & Pará \\
\hline 40 & & 1 & & & & & & & \\
\hline 41 & & - & & & & & & & \\
\hline 42 & 2 & 5 & 2 & 1 & & & & 1 & \\
\hline 43 & - & - & - & - & & & & - & \\
\hline 44 & 7 & 5 & 15 & - & & 3 & & 4 & \\
\hline 45 & - & & - & - & & - & & - & \\
\hline 46 & 2 & & 1 & - & & 6 & & 2 & 2 \\
\hline 47 & & & & - & & - & & - & - \\
\hline 48 & & & & 1 & 1 & 8 & 1 & 1 & 5 \\
\hline 49 & & & & - & & - & & & - \\
\hline 50 & & & & 1 & & 3 & & & 2 \\
\hline 51 & & & & & & & & & - \\
\hline 52 & & & & & & & & & - \\
\hline 53 & & & & & & & & & - \\
\hline 54 & & & & & & & & & - \\
\hline 55 & & & & & & & & & - \\
\hline 56 & & & & & & & & & 1 \\
\hline Sum & 11 & 11 & 18 & 3 & 1 & 20 & 1 & 8 & 10 \\
\hline
\end{tabular}

TABLE XIV

Amphisbaena fuliginosa, preanal pores, distributions of frequencies.

\begin{tabular}{l|c|c|c|c|c|c}
\hline Sample Pores & 6 & 7 & 8 & 9 & 10 & Sum \\
\hline Colombia & 4 & 2 & 3 & & & 9 \\
Trinidad & 7 & 3 & & & & 13 \\
Rondonia & 1 & 2 & 6 & & & 9 \\
Ecuador West & & 5 & 8 & 1 & & 14 \\
Ucayali & & 3 & 9 & & & 12 \\
Pará & & 1 & 8 & & & 9 \\
Iquitos & 1 & - & 17 & & & 18 \\
Ecuador East & & & 2 & 6 & 2 & 10 \\
Roraima & & 2 & 4 & 2 & & 8 \\
Panamá & & & 10 & & & 10 \\
Oriximiná & & 7 & 1 & & 8 \\
Serra da Mesa & 1 & - & 9 & 3 & & 13 \\
Manaus & & & 15 & 4 & & 19 \\
Suriname & & & 2 & 1 & 10 \\
Guyana & & & 5 & 3 & 2 & 10 \\
Aripuanã & & & 2 & 1 & 4 \\
\hline
\end{tabular}

ography. Ideally, they may constitute steps in transects between basic samples, indispensable in the search for intergradation. Alternatively, they may be compared with the geographically close basic samples, to refine the areal definitions of the taxa involved.

The 16 basic samples used are (coordinates in the Gazetteer):

Aripuanã (state of Mato Grosso, Brasil), 6 specimens.

Colombia, 10 specimens from 6 localities in Andean central Colombia (all in my 1951 paper): Barrancabermeja (Departamento de Santander); Medellin (Antioquia), Muzo (Boyacá), Paime (Cundinamarca); Honda (Tolima); San Pedro (Valle del Cauca).

Ecuador East, 11 specimens from Upper Amazonian Ecuador (Provincias) and Peru (Departamentos): Loreto (Prov. Napo); Avila (Prov. Napo); Baños to Canelos (Prov. Pastaza); Turula, Rio 
TABLE XV

Amphisbaena fuliginosa, preanal pores, statistics of the distributions of frequencies.

\begin{tabular}{l|c|c|c|c|c}
\hline Sample & $\mathrm{N}$ & $\mathrm{R}$ & $\mathrm{m}$ & $\mathrm{s}$ & $\mathrm{V}$ \\
\hline Colombia & 9 & $6-8$ & $6.9 \pm 0.31$ & 0.9 & 13.5 \\
Trinidad & 16 & $6-8$ & $7.1 \pm 0.23$ & 0.0 & 13.2 \\
Rondonia & 9 & $6-8$ & $7.6 \pm 0.24$ & 0.7 & 9.6 \\
Ecuador West & 14 & $7-9$ & $7.7 \pm 0.16$ & 0.6 & 7.9 \\
Ucayali & 12 & $7-8$ & $7.8 \pm 0.13$ & 0.5 & 5.8 \\
Pará & 9 & $7-8$ & $7.9 \pm 0.11$ & 0.3 & 4.2 \\
Iquitos & 18 & $6-8$ & $7.9 \pm 0.11$ & 0.5 & 6.0 \\
Ecuador East & 10 & $7-9$ & $8.0 \pm 0.21$ & 0.7 & 8.3 \\
Roraima & 8 & $7-9$ & $8.0 \pm 0.27$ & 0.8 & 9.5 \\
Panamá & 10 & 8 & 8.0 & & \\
Oriximiná & 8 & $8-9$ & $8.1 \pm 0.13$ & 0.4 & 4.4 \\
Serra da Mesa & 13 & $6-9$ & $8.1 \pm 0.21$ & 0.8 & 9.4 \\
Manaus & 19 & $8-9$ & $8.2 \pm 0.10$ & 0.4 & 5.1 \\
Suriname & 10 & $8-10$ & $8.4 \pm 0.22$ & 0.7 & 8.3 \\
Guyana & 10 & $8-10$ & $8.7 \pm 0.26$ & 0.8 & 9.5 \\
Aripuanã & 4 & $8-10$ & $8.8 \pm 0.48$ & 1.0 & 10.9 \\
\hline
\end{tabular}

\section{TABLE XVI}

Amphisbaena fuliginosa, preanal pores, Tukey's test.

\begin{tabular}{l|c|c|c}
\hline Sample & $\mathrm{m}$ & $\mathrm{N}$ & \\
\hline 1. Colombia & 6.9 & 9 & \\
2. Rondonia & 7.6 & 9 & \\
3. Ecuador West & 7.7 & 14 & \\
4. Ucayali & 7.8 & 12 & \\
5. Pará & 7.9 & 9 & \\
6. Iquitos & 7.9 & 18 & \\
7. Ecuador East & 8.0 & 10 & \\
8. Roraima & 8.0 & 8 & \\
9. Panamá & 8.0 & 10 & \\
10. Oriximiná & 8.1 & 8 & \\
11. Serra da Mesa & 8.1 & 13 & \\
12. Manaus & 8.2 & 19 & \\
13. Suriname & 8.4 & 10 & \\
14. Guyana & 8.7 & 10 & \\
15. Aripuanã & 8.8 & 4 & \\
\hline
\end{tabular}

Upano (frequently misspelled "Luoula", e.g. in my 1951 paper) (Prov. Morona - Santiago); Canelos (Prov. Pastaza); Rio Pastaza (Prov. Pastaza); Boca Santiago (Dept. Amazonas); Rio Cenipa (frequently misspelled "Cenepa") (Dept. Amazonas).

Ecuador West, 14 specimens from 7 localities in Ecuador west of the Andes: Santo Domingo de los Colorados (Prov. Pichincha); Riobamba (Chimborazo); 50 km E Loja (Zamora-Chinchipe); Bucay (Guayas).

Guyana, 10 specimens from Maccasseema, Georgetown, Kaieteur, Kalacoon, Kamakusa, Marudi River, Nappi (Kanuku Mts.).

Iquitos (Dept. Loreto, Peru), 18 specimens, all in the 1951 paper.

Manaus (state of Amazonas, Brasil), 18 specimens.

Oriximiná (state of Pará, Brasil), 8 specimens. Panamá, 10 specimens from the 1951 paper.

Pará, 9 specimens from the eastern part of the 
TABLE XVII

Amphisbaena fuliginosa, preanal pores, West-East transect.

\begin{tabular}{c|c|c|c|c|c|c|c|c|c|c}
\hline Pores & $\begin{array}{c}\text { W } \\
\text { Ecuador }\end{array}$ & $\begin{array}{c}\text { E } \\
\text { Ecuador }\end{array}$ & Iquitos & Leticia & $\begin{array}{c}\text { Taba- } \\
\text { tinga }\end{array}$ & Berurí & Manaus & $\begin{array}{c}\text { Itapi- } \\
\text { ranga }\end{array}$ & $\begin{array}{c}\text { Orixi- } \\
\text { miná }\end{array}$ & Pará \\
\hline 6 & & & 1 & & & & & & & \\
7 & 5 & & - & & & & & & & \\
8 & 8 & 2 & 17 & 1 & & 1 & 15 & 1 & 7 & 1 \\
9 & 1 & 6 & & & 1 & & 4 & & 1 & 8 \\
10 & & 2 & & & & & & & & \\
Sum & 14 & 10 & 18 & 1 & 1 & 1 & 19 & 1 & 8 & 9 \\
\hline
\end{tabular}

TABLE XVIII

Amphisbaena fuliginosa, preanal pores, Manaus-Colombia transect.

\begin{tabular}{c|c|c|c|c|c|c}
\hline Pores & Colombia & Villavicencio & Cucuí & Vista Alegre & Balbina & Manaus \\
\hline 6 & 4 & & & 1 & & \\
7 & 2 & & & & & \\
8 & 3 & 4 & 2 & & 3 & 16 \\
9 & & 1 & & & & 4 \\
Sum & 9 & 5 & 2 & 1 & 3 & 20 \\
\hline
\end{tabular}

state of Pará, Brasil, and adjacent Maranhão: Belém; Highway BR-010 (“Belém-Brasilia”) km 93; Canindé, Rio Gurupí; Tomé-Açu; Açailandia.

Rondonia, 9 specimens from Santa Barbara; Alto Paraíso; Cachoeira de Nazaré, Rio Machado (or Ji-Paraná); Highway RO-399 km 1; Highway RO-399 km 5.

Roraima, 10 specimens from Vila Pacaraima; Tepequém Mt.; Island of Maracá, Rio Uraricoera; Maloca Mangueira; Cachoeira do Cujubim, Rio Catrimani; Rio Barauana at Highway BR-210; Apiaú.

Serra da Mesa (state of Goiás, Brasil), 12 specimens, plus one from nearby Piracanjuba (13 in all).

Suriname, 10 specimens from Paramaribo, Christiaankondre and unspecified localities.

Trinidad, 17 specimens from several localities in the island. This sample is included only to make the data available. It cannot at present be included in the analysis for lack of Venezuelan materials.
Ucayali, 12 specimens from the valley of the Rio Ucayali, Peru (Depts. Loreto and Ucayali): Cashiboya; Contamana; Rio Cushabatay; Pampa Hermosa; Pucallpa; Reforma; Requena; Roaboya.

The localities with one or a few specimens are listed in the transect tables (Tables III, IV, V, VIII, IX, XII, XIII, XVII, XVIII). The sample "Acre" comprises two specimens, one from Porto Walter, the other from Tarauacá.

All localities except those in the state of Goiás (Serra da Mesa and Piracanjuba), which are in cerrado, are in areas primarily covered by rain forest.

The Gazetteer at the end contains the coordinates of all localities.

\section{ANALYSIS}

\section{Color Pattern (Figure 1)}

The color pattern of Amphisbaena fuliginosa is an intriguing subject. On one side, it is unique in 

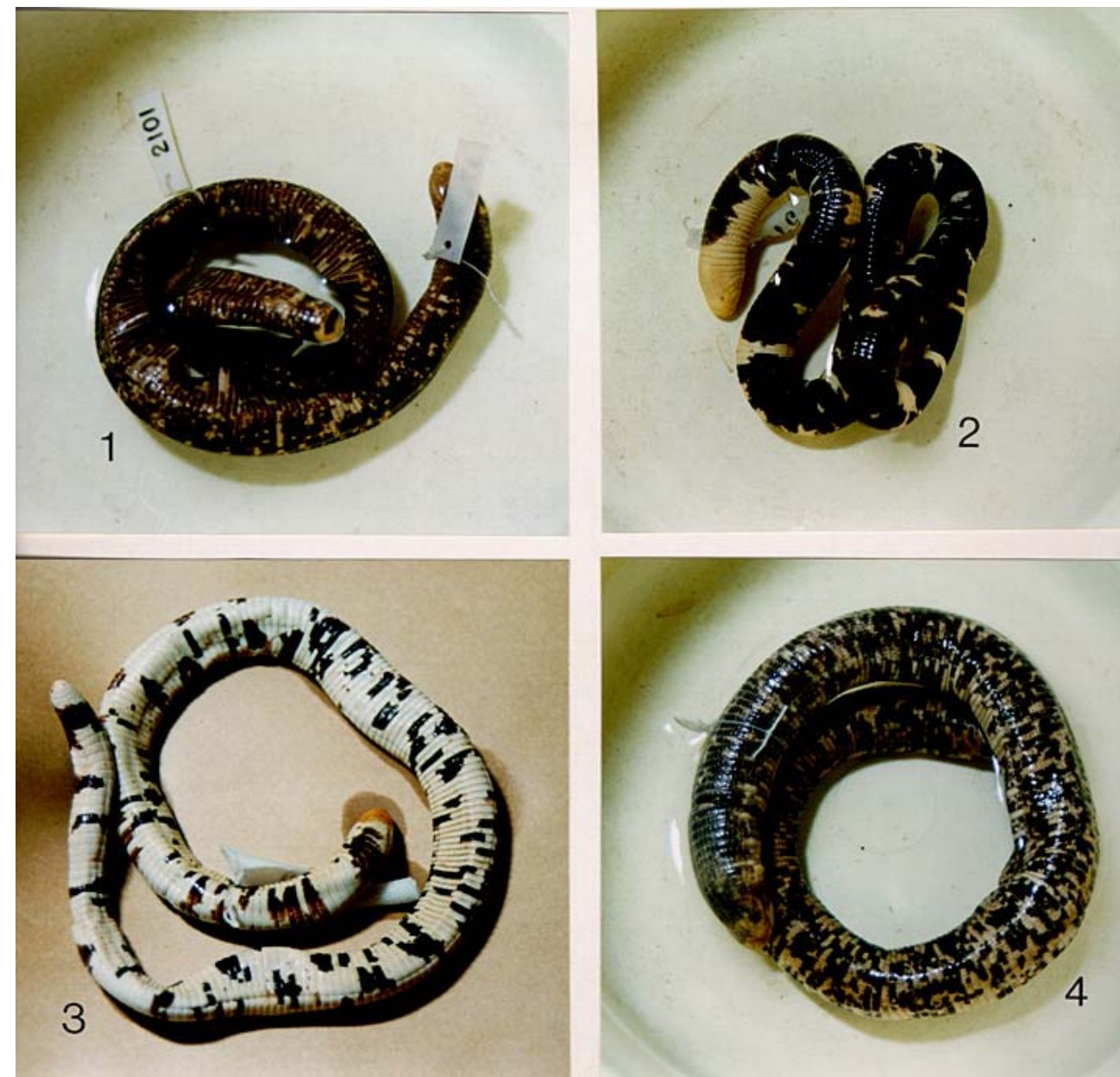

Fig. 1 - 1, Amphisbaena fuliginosa varia, MZUSP 2101, Panamá. 2, A. f. amazonica, MZUSP 57863, Manaus, Amazonas. 3, A. f. bassleri, MZUSP 6430, Loreto, Napo, Ecuador. 4, A. $f$. wiedi, MZUSP 87695, Serra da Mesa, Goiás.

the genus, unequivocally linking together a large number of populations over a vast area. It is, in fact, so characteristic that, until I (on general principles) started counting scales in 1950, there had been no preoccupation with geographical differentiation. On the other hand, once one is aware, it is easy to see that there are marked variations of the basic type, with definite spatial arrangements.

It is a brindled pattern, dark spots on a lighter background, with variations on back, belly and top of the head. The ground color varies from creamy yellow to dusky pink to purplish. The spotting varies from definitely black to just a little darker than the ground color, either coinciding with the borders of individual segments or being more or less diffuse.

In Panamá (Figure 1: 1) and Colombia the ground color is a dirty pinkish; the spotting is smudgy, a little darker than the background.

In Iquitos, the Ucayali and eastern Ecuador (Figure 1: 3), the design is strikingly different: the ground color is very light, clear yellow or white; the dorsal pattern is reduced, tending to form narrow transverse well-marked black bands that reach down the flanks but not across the belly. 


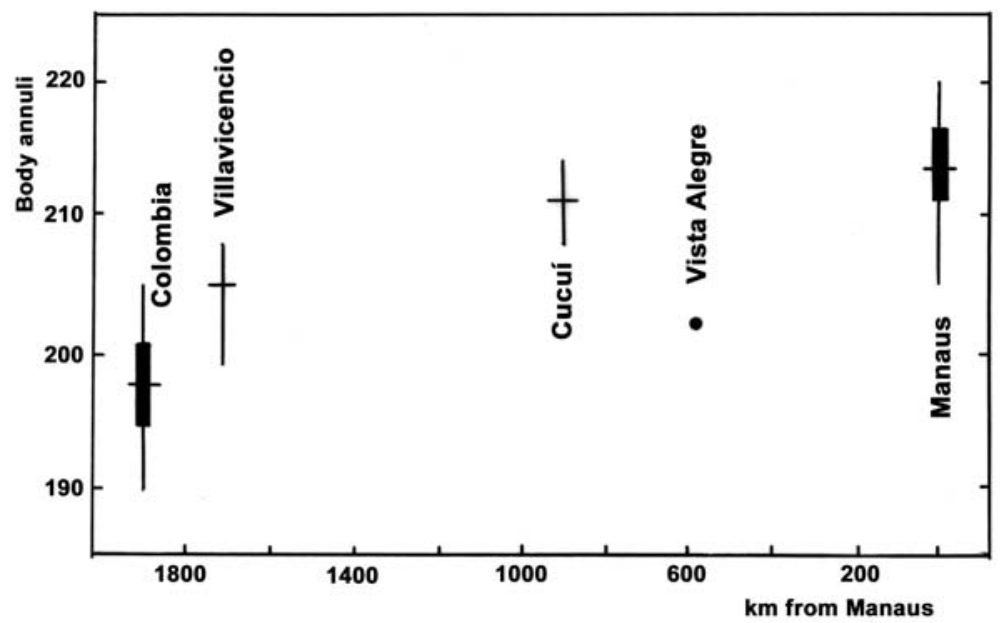

Fig. 2 - Amphisbaena fuliginosa, body annuli, Colombia-Manaus transect.

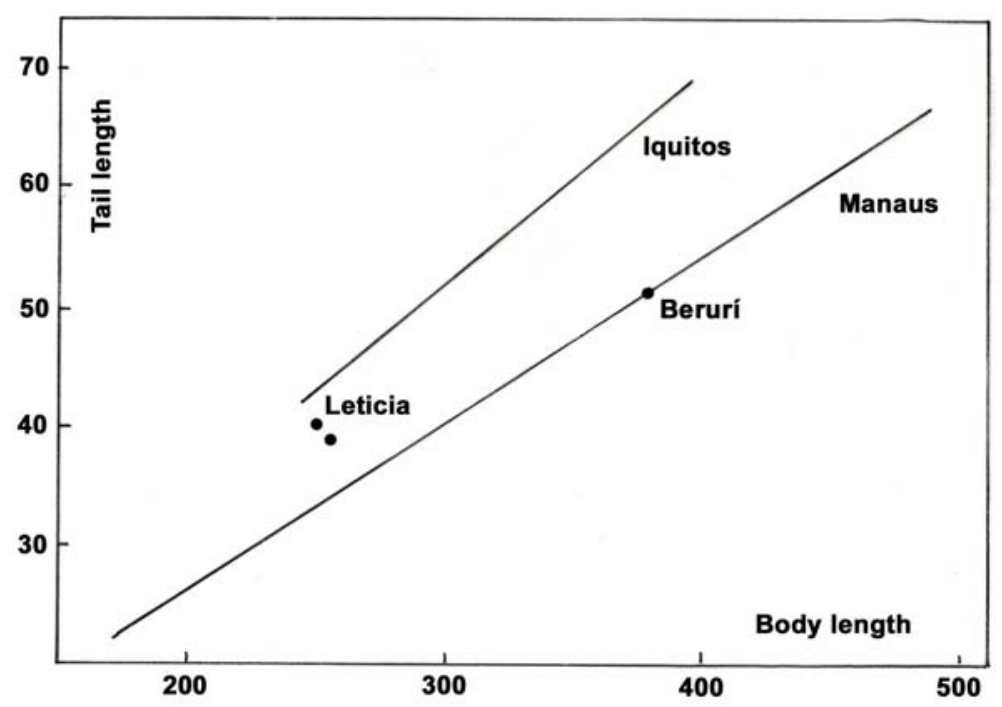

Fig. 3-Amphisbena fuliginosa, regression of tail length on body length, ManausIquitos transect.

In Manaus (Figure 1: 2) the ground color is light, yellowish; the spotting is black, denser in front and sparser behind and especially on the belly. Twenty of the 21 specimens seen have immaculate heads; one shows a minuscule black spot. All Amazonian specimens east of Manaus, show this color pattern; only one example from Belém has a small spot on the head.
Guianan and Roraiman specimens have a color pattern similar to that of Manaus, but the heads are consistently spotted.

Finally, the Goiás (Figure 1: 4) and Santa Maria specimens have dark purplish backs, at times distinctly mottled. The head is smudged; there is frequently on each side of the nape a lighter, but still smudged marking, almost an interrupted collar. The 

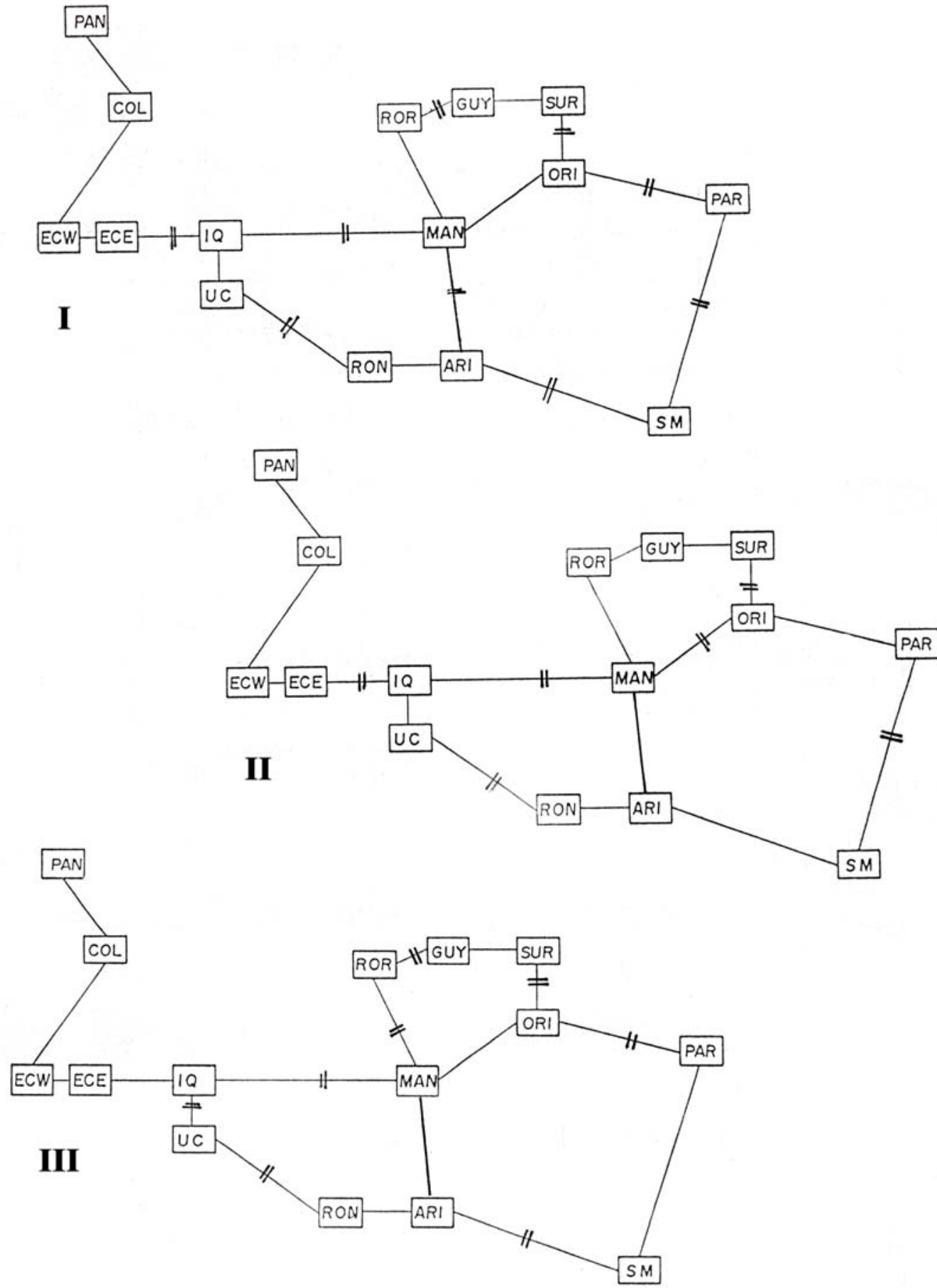

Fig. 4 1-3 - Spatial relationships of the distributions of meristric characters. 1. Body annuli. 2. Tail annuli. 3. Segments to a midbody annulus. Samples: ARI, Aripuanã. COL, Colombia. ECE, ECW, East and West Ecuador. GUY, Guyana. IQ, Iquitos. MAN, Manaus. ORI, Oriximiná. PAN, Panama. PAR, Pará. RON, Rondônia. ROR, Roraima. SM, Serra da Mesa. SUR, Suriname. UC, Ucayali. Cross lines indicate statistically significant differences. 


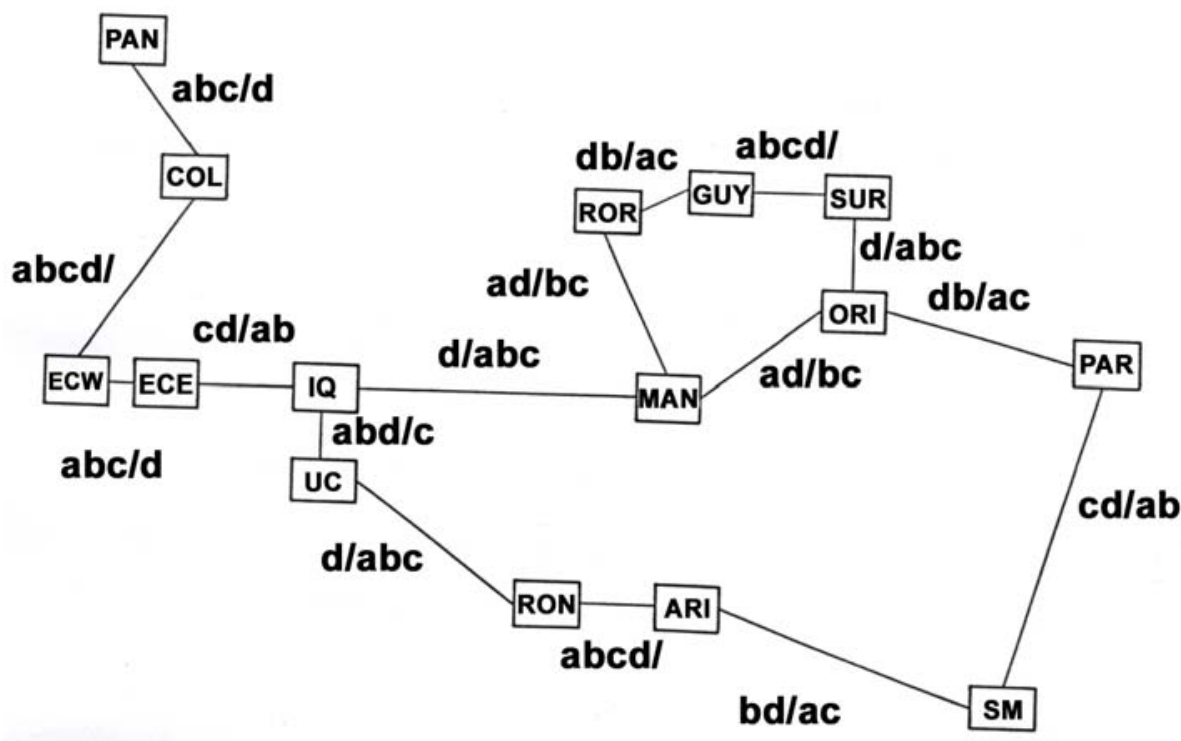

Fig. 5 - Summary of Figure 4 1-3. Conventions for samples as in Figure 4 1-3. Small letters to the left of the dash mean characters in which the two samples do not differ significantly; to the right of the dash, characters with significant differences. $a$, body annuli. $b$, tail annuli. $c$, segments to a midbody annulus.

belly is usually straw-colored, with incomplete dark crossbands, usually one annulus wide. This color pattern is also shown by the Aripuanã, Maranhão and Gurupí specimens.

Clear intergradation is found in several areas. In western Ecuador the Colombian and Iquitos patterns intergrade; for instance, of three Riobamba specimens, one has a definitely Colombian cast, the other two are intermediate. The Cucuí and Villavicencio specimens are intermediate between Manaus and Colombia. Leticia agrees better with Iquitos than with Manaus, the head being distinctly spotted.

\section{Scale Counts}

Body annuli (Tables I-V, Figure 2, and especially Figure 4-I). This, as said, is a very important character, showing considerable geographic variation. The major areas of homogeneity are Panamá + Colombia, Guyana + Surinam and Rondonia + Aripuanã + Serra da Mesa. Otherwise there is not a general pattern: it is apparently a case of marked inter-deme variation (Carson 1987).

The transects are highly interesting. The Ma-
naus-Colombia transect (Table V, Figure 4-I) shows clear clinal transition. The West-East transect (Table IV) shows a short western cline, broad stability in central Amazonia and a sharp break in Pará. Finally, a southern transect (Table III), including the southern Brasilian localities ordered from West to East, shows that the Acre, Rondonia and Aripuanã samples are intermediate between the Ucayali + Iquitos and the northeastern samples.

Tail annuli (Table VI-IX, Figure 4-II). Again the northwestern samples are in full agreement among themselves. From Iquitos to Manaus and from Manaus to Pará the variation is roughly clinal. The southern samples are homogeneous, as are the Guianas.

Segments (Tables X-XIII, Figure 4-III). From Panamá to Iquitos there is uniformity; breaks occur to the east and south of Acre. Other areas of stability are the Guianas, Manaus + Oriximiná + Rondonia + Aripuanã, and Serra da Mesa + Pará.

Preanal pores (Tables XIV-XVIII). The geography of preanal pores is thoroughly fragmentary. 


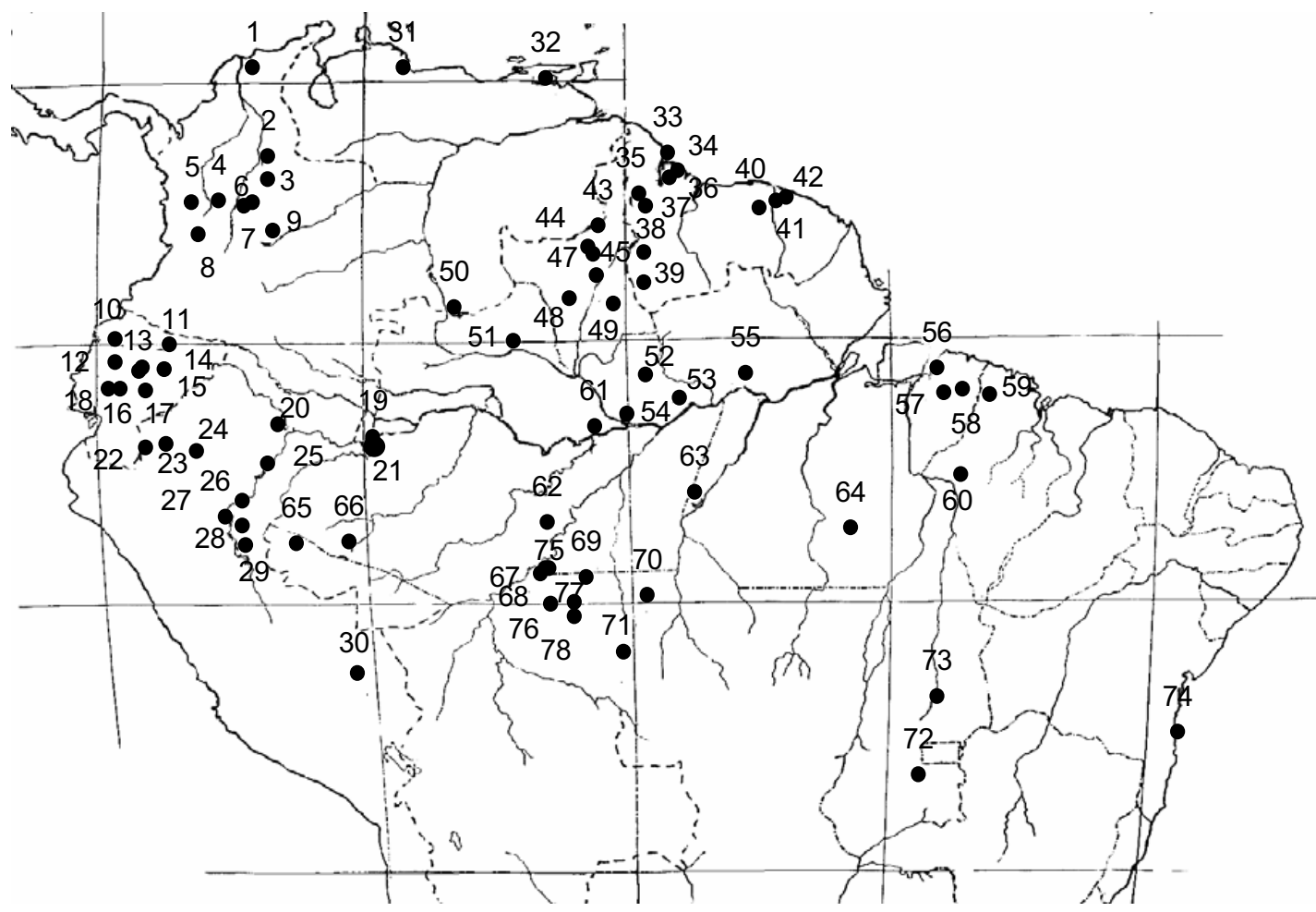

Fig. 6 - South American localities from which specimens were available. 1, Rio Frio. 2, Barrancabermeja. 3, Medellin. 4, Muzo. 5, Caño Las Animas ; Andagoya; Peña Lisa. 6, Honda. 7, Paime. 8, San Pedro. 9, Villavicencio. 10, Santo Domingo de los Colorados. 11, Avila; Loreto. 12, Pichilingue. 13, Baños. 14, Riobamba. 15, Canelos. 16, Bucay. 17, Turula. 18, Rio Daule; Guayaquil. 19, Loja. 20, Iquitos. 21, Leticia. 22, Rio Cenipa. 23, Boca Santiago. 24, Rio Pastaza. 25, Requena. 26, Cashiboya; Reforma. 27. Contamana; Rio Cushabatay; Pampa Hermosa. 28, Roaboya. 29, Pucallpa, 30, Rio San Gaban. 31, Riecito. 32, Caripito. 33, Maccasseema. 34, Georgetown. 35, Kamakusa. 36, Kalacoon. 37, Kaieteur. 38, Nappi. 39, Marudi River. 40, Paramaribo. 41, Chistiaankondre. 42, Saint Laurent du Maroni. 43, Vila Pacaraima. 44, Tepequém. 45, Maloca Mangueira. 46, Ilha de Maracá. 47, Apiaú. 48, Cachoeira do Cujubim. 49. Rio Barauana at Highway BR-210. 50, Cucuí, 51, Vista Alegre. 52, Balbina. 53, Itapiranga. 54, Manaus. 55, Oriximiná. 56, Belém. 57, Tomé Açu. 58, BR-010 km 93. 59, Canindé. 60, Açailandia. 61, Berurí. 62, Humaitá. 63, Jacareacanga. 64. Serra de Kukoinhokren. 65, Porto Walter. 66. Tarauacá. 67, Alto Paraíso. 68, Santa Barbara. 69, Cachoeira de Nazaré. 70, Aripuanã. 71, km 1; km 5 Highway RO-399. 72, Piracanjuba. 73, Serra da Mesa. 74, Santa Maria Eterna. 75, Charobamba. 76, Sorata. 77, Tipuani. 78, Las Yungas.

\section{TAIL LENGTH}

Ifeel incapable of analyzing the ensemble of the geographic variation of relative tail length (Tables XIX$\mathrm{XX)}$. I find it worthwhile, though, to examine the relationships between some pairs of geographically adjacent samples.

The difference between Iquitos and Manaus is striking; the intervening samples (Leticia and Berurí) are clearly intermediate (Figure 3). East of
Manaus there is uniformity. Roraima differs significantly from Guyana.

\section{CONCLUSION}

The main features of this geographic scenario seem to be:

1. There is only one species, A. fuliginosa, involved. 


\section{TABLE XIX}

Amphisbaena fuliginosa, statistics of the regression of tail length on body length.

\begin{tabular}{l|c|c|c|c|c|c|c}
\hline Samples & $\mathrm{N}$ & $\mathrm{R}(\mathrm{x})$ & $\mathrm{R}(\mathrm{y})$ & $\mathrm{b}$ & $\mathrm{a}$ & $\mathrm{F}$ & $\mathrm{r}^{2}$ \\
\hline Panamá & 5 & $240-350$ & $36-52$ & $0.145 \pm 0.0062$ & $1.56 \pm 2.640 \mathrm{~ns}$ & $524.319 * * *$ & 0.9943 \\
Colombia & 8 & $115-310$ & $19-45$ & $0.135 \pm 0.024$ & $2.76 \pm 3.162 \mathrm{~ns}$ & $44.146 * * *$ & 0.8803 \\
Ecuador West & 14 & $220-360$ & $34-62$ & $0.148 \pm 0.0228$ & $2.00 \pm 2.057 \mathrm{~ns}$ & $41.922 * * *$ & 0.7921 \\
Ecuador East & 5 & $130-380$ & $20-64$ & $0.158 \pm 0.0327$ & $5,360 \pm 7.836 \mathrm{~ns}$ & $23.402 *$ & 0.8864 \\
Iquitos & 15 & $245-450$ & $39-75$ & $0.170 \pm 0.0183$ & $0.62 \pm 2.825 \mathrm{~ns}$ & $80.584 * * *$ & 0.8695 \\
Ucayali & 11 & $105-365$ & $16-62$ & $0.170 \pm 0.0163$ & $-1.68 \pm 3.740 \mathrm{~ns}$ & $109.350 * *$ & 0.9240 \\
Manaus & 11 & $170-330$ & $21-40$ & $0.135 \pm 0.0158$ & $-0.77 \pm 1.902 \mathrm{~ns}$ & $72.996 * * *$ & 0.8902 \\
Roraima & 8 & $250-360$ & $38-56$ & $0.147 \pm 0.0386$ & $2.78 \pm 2.456 \mathrm{~ns}$ & $14.463 * *$ & 0.7068 \\
Guyana & 8 & $195-420$ & $29-55$ & $0.113 \pm 0.0132$ & $7.51 \pm 2.899 *$ & $73.279 * * *$ & 0.9243 \\
Surinam & 7 & $130-350$ & $19-51$ & $0.142 \pm 0.0107$ & $1.86 \pm 4.505 \mathrm{~ns}$ & $176.409 * * *$ & 0.9861 \\
Oriximiná & 5 & $174-252$ & $21-29$ & $0.080 \pm 0.0460$ & & $3.061 \mathrm{~ns}$ & \\
Pará & 6 & $225-375$ & $30-50$ & $0.180 \pm 0.0397$ & $-13.44 \pm 3.177 * * *$ & $25.503 *$ & 0.8368 \\
Rondonia & 5 & $150-275$ & $20-40$ & $0.148 \pm 0.0151$ & $-1.85 \pm 3.318 \mathrm{~ns}$ & $96.007 * * *$ & 0.9697 \\
Serra da Mesa & 8 & $284-353$ & $39-55$ & $0.205 \pm 0.0292$ & $-20.26 \pm 1.985 * * *$ & $49.457 * * *$ & 0.8918 \\
\hline
\end{tabular}

TABLE XX

Amphisbaena fuliginosa, regression of tail length on body length, Tukey's test for the intercept.

\begin{tabular}{l|l}
\hline Sample & \\
\hline Guyana & \\
Roraima & \\
Surinam & \\
Manaus & \\
Colombia & \\
Panamá & \\
Rondonia & \\
Ecuador West & \\
Ecuador East & \\
Ucayali & \\
Iquitos & \\
Serra da Mesa & \\
\hline
\end{tabular}

2. This species occupies continually one very large area, subdivided into two equally very large adjacent territories, in which occur two contrasting and well-characterized plant formations, rainforest and cerrado. There is one locality in the Atlantic forest.
3. In the forested territory the species is obviously in a stage of advanced but still incomplete differentiation. There are broad areas of welldefined and characteristic color patterns, separated by relatively narrow transition belts. The data on quantitative characters do not quite permit to say that they are exactly coextensive with that of the color pattern, but the location of the transitional belts is highly suggestive.

4. There are not yet adequate data on cerrado populations. A first impression is, as said, one of strong inter-deme differentiation (Carson 1987).

I have no doubt that this situation is the result of a process of differentiation in forest refugia, as proposed by Haffer (1969) and by Vanzolini and Williams (1970). The differentiation, if incomplete, is well-marked, and the geographic units can be easily and unambiguously identified. This why I decided in 1951, and reiterate it now, to treat them as subspecies.

The general subspecific pattern is superimposed on a scheme of pronounced inter-deme differentiation, as indicated by the relatively high number 
TABLE XXI

Amphisbaena fuliginosa, statistics of the regression of head width on body length.

\begin{tabular}{l|c|c|c|c|c|c|c}
\hline Sample & $\mathrm{N}$ & $\mathrm{R}(\mathrm{x})$ & $\mathrm{R}(\mathrm{y})$ & $\mathrm{b}$ & $\mathrm{a}$ & $\mathrm{F}$ & $\mathrm{r}^{2}$ \\
\hline Aripuanã & 6 & $288-385$ & $11-16$ & $0.0329 \pm 0.01740$ & & $3.554 \mathrm{~ns}$ & \\
Manaus & 8 & $193-490$ & $7-17$ & $0.0358 \pm 0.00357$ & $0.25 \pm 1.321 \mathrm{~ns}$ & $100.133 * * *$ & 0.9435 \\
Oriximiná & 7 & $174-300$ & $7-11$ & $0.0341 \pm 0.00382$ & $0.90 \pm 0.580 \mathrm{~ns}$ & $79.762 * * *$ & 0.9410 \\
Pará & 8 & $225-325$ & $10-12$ & $0.0158 \pm 0.00359$ & $6.84 \pm 0.274 * * *$ & $19.416 * * *$ & 0.7639 \\
Rondonia & 9 & $150-320$ & $7-12$ & $0.0278 \pm 0.0826$ & $2.17 \pm 0.632 *$ & $11.311 *$ & 0.7860 \\
Roraima & 11 & $250-365$ & $9-15$ & $0.0504 \pm 0.00757$ & $-3.69 \pm 0.397 * * *$ & $44.328 * * *$ & 0.8312 \\
Serra da Mesa & 13 & $264-353$ & $10-15$ & $0.0552 \pm 0.001230$ & $-4.76 \pm 0.510 * * *$ & $20.113 * * *$ & 0.6465 \\
\hline
\end{tabular}

TABLE XXII

Amphisbaena fuliginosa, statistics of the distributions of frequencies of the meristic characters of the subspecies.

\begin{tabular}{l|l|l|c|c|c|c}
\hline Character & Subspecies & $\mathrm{N}$ & $\mathrm{R}$ & $\mathrm{m}$ & $\mathrm{s}$ & $\mathrm{V}$ \\
\hline Body annuli & varia & 24 & $190-205$ & $197.8 \pm 0.72$ & 3.5 & 1.8 \\
& fuliginosa & 21 & $192-218$ & $205.4 \pm 1.33$ & 6.1 & 3.0 \\
& bassleri & 30 & $204-215$ & $208.3 \pm 0.53$ & 2.9 & 1.4 \\
Tail annuli & amazonica & 22 & $206-220$ & $213.1 \pm 0.84$ & 4.01 & 1.9 \\
& wiedi & 31 & $180-210$ & $196.5 \pm 1.23$ & 6.9 & 3.5 \\
& varia & 19 & $23-27$ & $24.6 \pm 0.27$ & 1.2 & 4.7 \\
& fuliginosa & 15 & $24-29$ & $25.6 \pm 0.35$ & 1.4 & 5.3 \\
& bassleri & 27 & $26-30$ & $28.2 \pm 0.24$ & 1.3 & 4.4 \\
& amazonica & 16 & $20-28$ & $24.9 \pm 0.35$ & 1.4 & 5.7 \\
& wiedi & 22 & $23-28$ & $24.5 \pm 0.28$ & 1.3 & 5.3 \\
& varia & 24 & $40-50$ & $45.2 \pm 0.56$ & 2.8 & 6.1 \\
& fuliginosa & 20 & $40-56$ & $47.7 \pm 0.89$ & 4.0 & 8.3 \\
& bassleri & 30 & $38-46$ & $43.1 \pm 0.33$ & 1.8 & 4.2 \\
& amazonica & 23 & $44-52$ & $47.4 \pm 0.43$ & 2.0 & 4.3 \\
& wiedi & 31 & $40-52$ & $48.3 \pm 0.62$ & 3.4 & 7.1 \\
& varia & 23 & $6-8$ & $7.4 \pm 0.18$ & 0.8 & 11.4 \\
& fuliginosa & 21 & $8-10$ & $8.6 \pm 0.18$ & 0.8 & 9.3 \\
& bassleri & 30 & $6-8$ & $7.8 \pm 0.08$ & 0.5 & 5.9 \\
& amazonica & 23 & $8-9$ & $8.2 \pm 0.08$ & 0.4 & 4.7 \\
& wiedi & 29 & $6-10$ & $8.1 \pm 0.17$ & 0.9 & 11.1 \\
\hline
\end{tabular}

of statistically significant differences between adjacent areas of comparatively similar ecology. This fractured pattern can well be expected from a subterranean animal in early (or interrupted) stages of speciation. On the other hand, there is abundant evidence of gene flow, especially the presence of areas of character stability and the smoothness of the transitions. It is to me quite obvious that there is no way of making sense of such a pattern without recourse to a causal explanation - a model of geographical differentiation. The fragmented character of the pattern indicates the presence of isolated demes at the time of differentiation. 
TABLE XXIII

Amphisbaena fuliginosa, statistics of the regression of tail length on body length, subspecies.

\begin{tabular}{l|c|c|c|c|c|c|c}
\hline Subspecies & $\mathrm{N}$ & $\mathrm{R}(\mathrm{x})$ & $\mathrm{R}(\mathrm{y})$ & $\mathrm{b}$ & $\mathrm{a}$ & $\mathrm{F}$ & $\mathrm{r}^{2}$ \\
\hline A.f. varia & 26 & $115-360$ & $19-62$ & $0.150 \pm 0.0120$ & $0.26 \pm 1.656 \mathrm{~ns}$ & $156.860^{* * *}$ & 0.8613 \\
A.f. fuliginosa & 15 & $130-420$ & $19-55$ & $0.125 \pm 0.0086$ & $4.74 \pm 2.604 \mathrm{~ns}$ & $212.134 * * *$ & 0.9423 \\
A.f. amazonica & 25 & $170-342$ & $21-50$ & $0.143 \pm 0.0125$ & $-2.85 \pm 1.436 \mathrm{~ns}$ & $130.540^{* * *}$ & 0.8502 \\
A.f. bassleri & 26 & $105-450$ & $16-75$ & $0.177 \pm 0.0155$ & $-2.27 \pm 2.458 \mathrm{~ns}$ & $235.468^{* * *}$ & 0.9075 \\
A.f. wiedi & 16 & $150-385$ & $20-55$ & $0.147 \pm 0.0084$ & $-1.82 \pm 2.223 \mathrm{~ns}$ & $304.939 * * *$ & 0.9561 \\
\hline
\end{tabular}

How A. fuliginosa, which clearly originated in Amazonia, came to invade the cerrado is a very interesting problem, to which at present there are no decisive clues. Apparently there were two cycles in the general shaping of the territory: first differentiation in Amazonia and next occupation of the cerrado. Examining the obvious possibilities, the species may simply have expanded its area across the ecological frontier, protected by its subterranean habitus. Alternatively, it may have passed through an intermediate stage, involving a "vanishing refuge" (Vanzolini and Williams 1981): (i) a forest population gets locally adapted to ecotonal conditions; (ii) disappearance of the forest and persistence of the animal in the site lead to further in loco adaptation to open conditions; (iii) at the same time the retreat of the forest isolates the population in its new environment, with all attendant chances for differentiation.

Otherwise, A. fuliginosa may have taken part in the last wave of invasion of Central Brasil by Amazonian forests (Ledru 1993, Vanzolini 1997), being left behind in the succeeding withdrawal.

In trying to choose an alternative, one consideration is that it would at first sight seem easy for a fossorial animal to cross an ecological barrier occurring on the surface of the landscape. However the differences between rain forest and cerrado soils are extreme, in all physical and chemical properties. Contrariwise, it should be taken into account that the contacts between morphoclimatic domains are not gradual, but broad, complex, sectorial (Ab'Saber 1977) - which has always been an encumbrance to clinal theories of geographical speciation, but would offer way-stations for animals crossing the barrier. Finally sharp differences in small spaces would tend to favor a vanishing refuge model.

Any of these alternatives may have happened as a single event at a single place, or as repeated crossings, at the same or different moments, at different places, but always at times of minimal climatic contrast. Any further consideration of these matters must await further data - more collections adequately covering the cerrados, or convincing negative evidence. At present it is only possible to say that the event (or events), seems to have been relatively recent, as most cerrado events seem to be (Vanzolini 1997).

A special problem is raised by the sample from Santa Maria - incidentally the hypodigm of $A$. $f$. wiedi. It dates from the early nineteenth century and is the only sample known from the Atlantic forest, herpetologically the best explored region of Brasil. Amazonian animals with distribution extending into the Atlantic forest are no novelty (Vanzolini 1994). The actual problems are the failure to collect the animal again after almost two hundred years, and the fact that it does not visibly differ from specimens from the cerrados. Prince Max's locality may conceivably be in error, but I have no reason at present to doubt his data. It is one more case for further collecting, if only to ascertain negative information.

\section{ON IDENTIFICATION}

A frequent criticism of subspecies is that they are rather identifiable by provenance than by morphology. This is not the case here. Identification is, as 
said, ready and unambiguous. In fact, the practicability of the scheme has already been fully tested. I wrote the 1951 paper while a graduate student at the Museum of Comparative Zoology, Harvard University. When I submitted the paper, Mr. Arthur Loveridge, the curator of Herpetology, imposed, as a condition for acceptance, that I correctly identify at least $75 \%$ of a series of specimens of provenance unknown to me. This for two reasons: (i) that I, a Brasilian, was a "native" (Mr. Loveridge was an Englishman with a colonial African background), and (ii) that a renowned contemporary herpetologist was not able to identify $50 \%$ of his own subspecies. Mr. Loveridge gave me 14 specimens, and I provided correct provenances for the 14, which convinced him of the reality of the subspecies. (This immensely amused my then colleague W.L. Brown $\mathrm{Jr}$, the myrmecologist, who aptly remarked that the feat had nothing to do with the reality of subspecies, only with the robustness of the statistics).

\section{TAXONOMY}

\section{Characterization of the Species}

Head relatively massive, snout prominent, swollen. Body stocky, total length of adults usually 350 to 500 $\mathrm{mm}$, one specimen $555 \mathrm{~mm}$. Tail clavate; autotomy annulus, fifth to seventh.

Rostral moderate, low. Nasals large, in contact with the second supralabial. Prefrontal moderate. Postfrontals forming together a rough hexagon, wider than long. Three upper labials, the first smallest, the second and third variously divided and fused, at times suggesting preoculars or anterior suboculars. One true subocular, above the third labial, which may be horizontally split. Two irregular temporal series. Symphysial roughly anvil-shaped, sometimes fused with one of the infralabials, which are 3 or 4 , at times split or fused. Post-symphysial elongate, sometimes longitudinally split. Remaining scales of the mental region variable.

\section{Amphisbaena f. fuliginosa}

Linnaeus, 1758
Amphisbaena fuliginosa Linnaeus, 1758: 29, Type locality "America".

Amphisbaena vulgaris Laurenti, 1768: 66. Type locality not mentioned.

Amphisbaena magnifica Laurenti, 1768: 67. Type locality "America".

Amphisbaena flava Laurenti, 1768: 67. Type locality "America".

Amphisbaena americana Gray, 1844: 70. Nomen novum pro Amphisbaena fuliginosa Linnaeus.

Amphisbaena fuliginosa fuliginosa, Vanzolini, 1951: 60. Revision.

Type locality: Linnaeus (1758: 229) had two specimens, which have survived (Vanzolini 1951: 56-59). A description of the specimen still preserved at Uppsala is contained in Linnaeus's Amoenitates Academicae (Linnaeus 1749, Surinamensia Grilliana; Lönnberg 1896). It seems clear, judging by the specimen's characters (Vanzolini 1951: 59), and is compatible with historical and geographical information, that the type locality must have been Suriname, very probably the region around Paramaribo. In agreement with Myers and Böhme (1996), I see no virtue in the designation of type localities by fiat, just to fill a void. However, there is always purpose in clearing moot points, using circumstantially relevant information, should the need ever arise (Vanzolini 1999: 12).

Meristic characters: Body annuli 192-218; tail anuli 24-29; segments to a midbody annulus 40-56; preanal pores 8-10.

Color pattern: Ground color whitish; spotting black, clear-cut, denser on the front part of the dorsum, sparsest on the belly. Top of head spotted.

Range: The Guianas.

\section{Amphisbaena fuliginosa varia} Laurenti, 1768

Amphisbaena varia Laurenti, 1768: 66. Type locality, Barro Colorado Island, by designation of neotype (Vanzolini 1951). 
Amphisbaena fuliginosa varia, Vanzolini, 1951: 61. Revision.

Meristic characters: Body annuli 192-205; tail annuli 23-27; segments to a midbody annulus 40-50; preanal pores 6-8.

Color pattern: Ground color a dirty pinkish; body markings smudgy, very dense, almost obliterating the ground color, equally dense on back, belly and top of the head.

Range: Panamá and Andean Colombia, extending into adjacent Ecuador and probably Venezuela.

\section{Amphisbaena fuliginosa bassleri}

Vanzolini, 1951

Amphisbaena fuliginosa bassleri Vanzolini, 1951: 61. Type locality Peru: Ucayali: Roaboya.

Meristic characters: Body annuli 204-215; tail annuli 26-30; segments to a midbody annulus 38-46; preanal pores 6-8.

Color pattern: Ground color white to yellowish. Dorsal markings black, transverse, not crossing the belly.

Range: Upper Amazonas in Ecuador and Peru, valley of the Ucayali into Peru. Rhodes (1963) discusses six specimens from La Paz (Charobamba, Sorata, Tipuani, Yungas) that can possibly be assigned to this subspecies. Using the data of my 1951 paper, she concludes that there is reasonable agreement in color pattern, and, principally, differences in the number of body and tail annuli, and relative tail length. I compared Rhodes's data with the present ones for the Ucayali sample: the differences in number of annuli persist, but there is excellent agreement in the regression of tail length on body length.

\section{Amphisbaena fuliginosa amazonica} Vanzolini, 1951

Amphisbaena fuliginosa amazonica Vanzolini, 1951: 62. Type locality Brasil: Amazonas: Manaus.

Meristic characters: Body annuli 206-220; tail annuli 20-28; segments to a midbody annulus 44-52; preanal pores 8-9.

Color pattern: Ground color yellowish. Body spotting clear-cut, denser on the back. Head practically always immaculate.

Range: "Baixo Amazonas", i.e., the course of the Rio Amazonas east of the mouth of the Rio Negro.

\section{Amphisbaena fuliginosa wiedi}

Vanzolini, 1951

Amphisbaena fuliginosa wiedi Vanzolini, 1951: 62. Type locality Brasil: Bahia, Santa Maria Eterna.

Note on the type locality: In 1951 I was not able to identify precisely the type locality of this subspecies. The hypodigm (AMNH 1091-1093) having been collected by Prince Maximilian zu WiedNeuwied, it was extremely probable that the locality would be in the Atlantic forest of southern Bahia. Now I have found it. It is still called Santa Maria, in fact Santa Maria Eterna. It lies about $55 \mathrm{~km}$ due West of Belmonte, where the Prince spent some month and a half in 1816, actively exploring the valley of the river then called Belmonte, now Jequitinhonha (Wied 1820-1821: chapter 11; Bokermann 1957: 227-229).

Meristic characters: Body annuli 180-210; tail annuli 23-28; segments to a midbody annulus 46-52; preanal pores 6-10.

Color pattern: Ground color purplish; back densely smudged; belly with few spots, usually incomplete cross bands one annulus wide.

Range: Brasil south of the Rio Amazonas, to the latitude of the upper Rio Tocantins.

\section{Comments}

Amphisbaena fuliginosa varia is a very coherent subspecies. It extends from Panamá to Ecuador, very uniform in color pattern, meristic characters and tail length, the only exception being a pocket of low preanal pores in Colombia. Its range coincides with that of many other species of amphibians and reptiles (Vanzolini and Heyer 1985). Its two neigh- 
bors are bassleri to the south and amazonica to the east. From bassleri it differs in color pattern, an extreme difference, and in number of body and tail annuli. In the case of color pattern, intergradation is clear, the locality of Riobamba being especially informative in this respect. In the meristic characters no intergradation has been perceived. From amazonica, varia markedly differs in color pattern; of the geographically intermediate samples, Villavicencio and Cucuí are also phenotypically intermediate and Vista Alegre is typical amazonica. There are also strong differences in the number of body annuli (Table V, intergradation clear) and in the number of tail annuli (no intergradation found).

A. f. fuliginosa, the subspecies that occurs in the Guianas, is also very coherent: character variation is concordant throughout. The color pattern is highly distinctive, very different from those of neighboring Roraima and Oriximiná. It is regrettable that no specimens are available from Amapá.

Roraima, although represented by a reasonably large sample, well prepared and with firm data, is hard to place at this time. It does not show much affinity with its next neighbor, amazonica. The distributions of frequencies of body annuli and of segments to a midbody annulus are peculiar. In color pattern it tends rather toward varia, geographically distant, than toward spatially closer fuliginosa and amazonica. On purely statistical grounds, Roraima might be made the site of still another subspecies, but clarification of its status must wait for good samples from Venezuela.

A. f. amazonica, most visibly identified by its immaculate white head and by the high number of body annuli, occcupies the middle valley of the Rio Amazonas. It differs markedly from bassleri, to the west at the same latitude, in every character but preanal pores. In the case of the quantitative characters there is clear integradation (Tables IV, IX, XIII, Fig. 3). To the east, toward Belém of Pará, the situation is less clear (Tables IV, IX, XIII). Unspotted heads prevail, but there is much irregularity in the quantitative characters.
When I first described this subspecies I duly stressed the immaculate head. Subsequently I had doubts and even regrets. In hindsight the character seemed somewhat unsubstantial in the context of such a complex color pattern: I expected numerous exceptions would soon start appearing. Quite the contrary: time showed it to be very reliable. Why this should be so in a fossorial animal is beyond me.

A. $f$. bassleri inhabits a stretch of the Upper Amazonas and goes deep south into Peru, by present evidence along the Ucayali and farther south into Puno, possibly, as said, into Bolivia. The striking color pattern, that is found in pure form also in Acre and Rondonia, is geographically quite stable; the scale counts are not: only the counts of tail annuli are characteristically high. To the east, on the southeastern edge of the range, there is intergradation with wiedi. The clinal belt is unmistakable, but extremely broad - some nineteen hundred kilometers (Tables III, VIII). This is certainly an area from which good collections are much wanted.

A. $f$. wiedi is, not suprisingly, the least coherent subspecies. The color pattern is uniform, but the quantitative characters show little regularity. I think this is to be expected: wiedi is the product of a late event or series of events. It is quite possible that it is still undergoing adaptation to local ecological conditions, under some regime of inter-deme competition and gene flow that can only be guessed at. One must wait for further materials from the domain of the cerrados, from which scarcely more than a dozen specimens are known.

\section{A NOTE ON THE REFUGE MODEL}

I have adopted, to explain the pattern of differentiation of A. fuliginosa on the northern, forested, part of its range, the model of Quaternary forest refuges, which to me continues to be the most parsimonious (besides orthodox) mechanism proposed to understand geographic differentiation in the American tropics - both for forest and for open formation species.

To my knowledge, a model of speciation based 
on paleoclimates was first proposed by Lönnberg (1926), who maintained that some African birds had undergone speciation in isolated patches of forest during former dry climatic episodes. This was a time when subspecies, especially avian, were the focus of much interest, to culminate in the late thirties and early forties with the seminal books by Dobzhansky (1937), Huxley (1940) and Mayr (1942). In spite of this interest, there was no research on speciation in South America, and especially no cogitation of past climates, until a relatively late date (Vanzolini 1993).

The model of forest refugia was independently and almost simultaneously proposed by Haffer (1969) and by Vanzolini and Williams (1970). The animal groups studied, respectively birds and lizards, were different, but the approach was essentially the same: a search for geoscientific historical facts that would explain the distribution patterns observed. Both papers concluded that differentiation was principally geographic, allopatric and driven by the changing coarse mosaics of forest and open formations consequent upon climatic cycles. The present continuous Amazonian forest would have been preceded, in drier times, by a vast extension of open formations containing "islands" of forest. In these patches, isolated remains of forest fauna would differentiate, to come together again (with varying outcomes of interaction) in the ensuing humid leg of the climatic cycle.

The model was readily adopted by systematists (see, e.g., the papers in Prance 1982, Whitmore and Prance 1987), but, in time, aroused opposition from paleoecologists - systematists in general stayed faithful. There has been considerable controversy.

Recently (December, 2001), the issue (16,3/4) of the journal Amazoniana honoring the limnologist Harald Sioli on his ninetieth birthday included four papers on the debate, by Haffer and Prance, by Colinvaux, Irion, Räsänen, Bush and Nunes de Mello, by van der Hammen and by Hooghiemstra. These papers very adequately summarize and bring to date the argument.
Haffer and Prance (2001: 579) review the history of the model, discuss pro and con arguments and, very important, analyze some misconceptions mistakenly erected as criticisms. Finally, they examine the applicability of rival models of allopatric speciation.

The discussion of the misconceptions (or misrepresentations), based essentially on Haffer (1993), includes, among others, the following points that I deem indispensable.

1. The model would have been based only on present biotic patterns. Actually, as said, the initial work combined distributional patterns with paleoecological (palynological and geomorphological) data. I know: I participated, and it has been a landmark in my life that this was the beginning of a long and rewarding association with Aziz Nacib Ab'Saber, better than whom nobody could have offered ingress into paleoclimatic matters, with ready and continuous application to the Brasilian reality around us. Haffer, a professional geologist, availed himself of his unmatched command both of the literature, ecologic and geoscientific, and of the field evidence, in Colombia and in Amazonia in general.

2. The model would have been designed for application to the Pleistocene only, and would thus imply that all patterns currently observable are Quaternary in age. This, as Haffer and Prance (2001: 590) express it, is a mere straw man, erected only to be knocked down. The claim was never made; stress was instead explicitly placed, both by Haffer (1969) and by Vanzolini and Williams (1970), on the recurrent nature of the process. Vanzolini and Williams (1970: 107) even mention the probability of phenomena of resonance, given the duration of topographic features, responsible for many relevant rainfall features, compared to the relative shortness of climatic cycles. It is matter of undisputed common knowledge among systematists 
that some speciation events date back to the Tertiary (Frailey 1986, Maxson and Heyer 1988).

3. Another misrepresentation, and one frequently alleged by opponents of the model (e.g. Colinvaux (1996) is that it implies arid climatic phases. This is another straw man: the assertion was never made by the originators of the model. There were arid phases in the Pleistocene (Kronberg and Benchimol 1993, Latrubesse and Franzinelli 1995, Latrubesse and Rancy 1998), but, for the model, all that is required is a climate (such as that of many parts of present Brasil, that has vast cerrados and caatingas, but not one single arid area) that will favor open vegetation over forests. Modern analogy points out mainly (but not exclusively) to cerrados, of which sizable enclaves nowadays exist in Amazonia. In a case study of the symmetrical problem of differentiation in islands of cerrado dispersed in a general forest, I have (Vanzolini 1997) calculated that, broadly speaking, to substitute cerrado for forest, a decrease will suffice of about 30 percent in the rainfall of an area with a suitably cool and dry winter. This conjuncture is found in many areas of present Amazonia (Salati et al. 1978), and the required decrease is modest indeed in view of estimated climatic parameters for the Quaternary (van der Hammen 2001, Markgraf 1993, Iriondo and Latrubesse 1994).

Haffer and Prance deal in sequence with some alternative models of allopatric speciation proposed for Amazonia. They examine in detail the shortcomings of the proposals of Bush (1994), Colinvaux (1998), Fjeldså et al. (1999) and Patton et al. (2000). I think their analysis is conclusive and see no need to return to the issue.

The next paper in the volume, by Colinvaux et al. (2001: 609-646) is entitled "A paradigm to be discarded: geological and paleoecological data falsify the Haffer and Prance refuge hypothesis of Amazonian speciation". This title gives a good in- dication of the emotional tone of the article. (Colinvaux, in another paper (1993: 475), says: "Thus the concept of Pleistocene forest refuges in the tropics is as intellectually barren as its predecessor concept of forest refuges in North America" - a revealing pearl of contumely and irrelevance).

Colinvaux et al. (2001) take arms again against the straw man of Amazonian aridity: "all available Amazonian pollen data, without exception and including new data, imply biome stability..."; "the 'aridity with refuges paradigm' now impedes Amazonian research, and should be discarded'.

In the next two papers of the same issue of Amazoniana, van der Hammen and Hooghiemstra (2001) thoroughly demolish Colinvaux's (1998) argument, especially the palynological part, with which van der Hammen deals masterly (partly based on Hooghiemstra and van der Hammen 1998).

I think this limelight-seeking line of thought needs no further attention.

Another area of research that has been very fruitful in the context is paleomammalogy, since it is easy to ascertain the ecological preferences of faunal assemblages. Since early days (Paula Couto 1944), southwestern Amazonia has provided several fossil mammal faunas clearly adapted to open formations - I may add to cerrado. In the context of the Upper Tertiary “'Great American Interchange', Webb and Rancy (1996; see also Rancy 1993) review the evidence and analyze the Late Pleistocene faunas of Acre. They sum up (1993: 350): “The Late Pleistocene fauna from western Amazonia lends support to this savanna hypothesis." The support, however, is restricted to the presence of "savannas" (cerrados), not extended to the refuge model as a whole: " A fundamental weakness of this rainforest theory is that the supporting evidence is derived from $\mathrm{Re}$ cent biotic patterns" (l.c.: 352). This reveals only that Webb and Rancy did not read Haffer (1969) and Vanzolini and Williams (1970) in the original. It also, and very curiously, goes frontally against the uniformitarianist principle (" the present is the key to the past"), which, since enunciated by Hutton and 
Lyell in the late eighteenth century, has been central to paleontological thought (e.g., Gould 1965). Since, however, two distinguished paleontologists disagree, we have to examine their reasons.

They argue (and this, incidentally, does not go against uniformitarianism, quite the contrary) that the locations of three of these fossil mammal faunas lie in areas designated as Late Pleistocene forest refuges. This is an obvious non sequitur. The existence of refuges and their location based on recent distributions are entirely different issues. "Patterns of distribution and differentiation do not prove the existence of refuges; they are simply compatible with the model' '... ' as to the location of refuges, it is a matter for geomorphologists and paleopalynologists." (Vanzolini 1993: 51). This was written before Colinvaux et al. (1996) for the first time located a refuge through pollen analysis, ironically enough within an area (the "Imeri Refuge") predicted by Haffer (1969).

Webb and Rancy (1996: 352) proceed: “Thus the western Amazon did not offer its mammal fauna a pure savanna setting, but rather a mobile habitat mosaic that included meandering belts of rain forest and perhaps seasonal flooding. Geomorphologists studying the same fluvial systems have proposed similar conclusions (Räsänen et al. 1987)'.

There are several points here in need of remark. I think that, inventing the expression "pure savanna setting", Webb and Rancy may have had in mind an expanse of cerrado without gallery forest or forest enclaves. If so, this does not exist and was never included in the model. Webb and Rancy could have read in Ab'Saber's papers (e.g., 1971, 1977) that gallery forests are an essential, integral part of the domain of the cerrados - Ab'Saber even calls the latter "domain of the highlands under cerrado, penetrated by gallery forests" (my translation).

Gallery forests, in the strict usage of the term an exclusive feature of the cerrados, begin at headwaters as marginal rows ("veredas") of burití palms (Mauritia). Soon downstream these veredas become thicker and more heterogeneous, but still limited to the levees ("restingas") of the streams. Next, they widen laterally on the backswamp ("varzea"), and later climb the moderate interfluves. When the "eyelashes" of two convergent rivers meet, we acknowledge to be in Amazonia (Ab'Saber 1996 a,b). Today, a large and well-known enclave is the “Mato Grosso de Goiás" (Waibel 1948, Vanzolini 1994: 176).

As to "meandering belts of rainforest", they are a figment of the imagination. There are neither rainforests nor meanders in the cerrados (Ab'Saber 1971: 2). On the other hand, enclaves of forest, of different types but (and this is the really significant point) with closed canopy, are another characteristic feature of cerrados (Labouriau 1966, Ab' Saber 1977).

Finally, "seasonal floodings", are also a constant trait of the physiology of cerrado rivers. They happen at the beginning of summer (wet season) and are responsible for two universally acknowledged key geomorphic processes, the shaping of the levees and the deposition of sediment in the backswamp.

Webb and Rancy (l.c.) consider their conclusion similar to that of Räsänen et al. (1987). However, the proposal of these Finnish authors has nothing to do with savannas or with meandering forest belts. They literally state in the Abstract of their article (l. c.: 1398): “...in the basinal forelands of the tectonically active Andes, the geological setting causes long-term fluvial perturbance. This leads to a temporally structured highly complex mosaic of fossil and present floodplains. These dynamics have been present with varying activity and geographic range during the Tertiary and Quaternary, providing site-turnover that has not been recognized by the biogeographic tradition of the Amazon basin'.

One must first consider how a model fitted to the basinal forelands of the Andes can be applied to the whole of Amazonia. Second, how could a fluid mosaic of "fossil and present floodplains" (of unspecified ecology, probably varzea forest) result in geographic, or any kind of isolation.

In what concerns me as a practicing systema- 
tist and biogeographer, this model of Räsänen et al. (1987) is just a game of words. (It has also been criticized, and found wanting, from other viewpoints Dumont et al. 1990, Latrubesse 1996).

One paleomammalogical paper that escaped Webb and Rancy's (1996) review is that by Campbell and Frailey (1985), who found a land mammal fauna with the same ecological implications in the nearby Rio Acre, in Peru.

Three additional paleomammalogical papers confirm the presence of cerrado-adapted faunas in the Late Pleistocene of southwestern Amazonia: Frailey (1986); Sant'Anna-Filho et al. (1996) and Latrubesse and Rancy (1998). The latter convincingly review the geology of this area so fertile in Quaternary fossils.

Some papers that I find important were omitted in the Amazoniana (2001) debate. Latrubesse and Ramonell (1994) review the paleontological literature and, with basis on recent analogs, propose a most interesting model of wind circulation and general climate for southwestern Amazonia during the Last Glacial. They conclude that the area, then under cerrado, had a longer and more pronounced dry season than at present, and that the short spells of cold weather ("friagens") consequent upon the penetration of polar fronts were more frequent and ecologically important (see also Iriondo and Latrubesse 1994).

Dumont et al. (1990) deal with the neotectonics of the Upper Amazon, and conclude that "the great age and stability of the upland ecosystems, and the rather constant ecological conditions (including gap-phase regeneration) in the under-story are still the most convincing explanation of the high species diversity within upland forest.' This belated revival, simply stated, without any support, of the gratuitous “Urwald"' concept (Schwabe 1969, critique in Vanzolini and Williams 1970: 108), apparently shared by Colinvaux (1996), needs hardly any comment in the light of current research on speciation. But, for the simple sake of argument, it could again be asked, how to extend a strictly juxta-Andean process to the whole of Amazonia?

Finally, there is a most interesting detailed scenario of Amazonian ecology in the Late Pleistocene (Iriondo and Latrubesse 1994: 127): the general vegetation would have been cerrado, with a strongly seasonal climate, rainfall $850-1000 \mathrm{~mm} / \mathrm{yr}$, the dry atmosphere resulting in limited local recycling of water as precipitation. This seems to me a very sensible scenario, except for the rainfall, that I find too low.

The llanos of the Orinoco, that Iriondo and Latrubesse cite as a modern analog, receive 1300$1400 \mathrm{~mm} / \mathrm{yr}$ (Tamayo 1972). Turning to Brasil, I took data (Brasil, Escritório de Meteorologia, 1968) from twelve localities I am sure are in the core of the cerrados; the range was $1072-1665 \mathrm{~mm} / \mathrm{yr}$, the mean $1428 \pm 60.6 \mathrm{~mm}$. For eight equally undoubted caatinga localities I got a range of 497-922 mm/yr, mean $712 \pm 49.5 \mathrm{~mm}$. Beyond doubt, the conjecture of Iriondo and Latrubesse fits caatingas better than cerrados. Caatingas certainly have existed in Amazonia: they left behind white sands and stone-lines (Ab'Saber 1979). But it would be rash to generalize their climatic features to all of Late Pleistocene Amazonia; Ab'Saber himself (l.c.) makes the point very clearly.

So I conclude that, after all these years and controversies, the refuge model stands virtually as originally proposed. The only change I would suggest would be to substitute a model of morphoclimatic domains for the simple consideration of types of vegetation.

A morphoclimatic domain (Ab'Saber 1967, 1977) is an area of sub-continental extent with characteristic features of topography, drainage, climate, soil and vegetation. In the case of the cerrados the topography is one of low plateaus, gentle, rolling at most. The drainage is dendritic, highly hierarchical. The climate is mesic, with a dry, cool winter and a wet warm summer. The soils are very profound (up to 30 meters), and guarantee water supply to the deep roots of the vegetation, during the dry season. Cerrados are not summer-deciduous, 
APPENDIX

Specimens used.

\begin{tabular}{|c|c|c|c|c|c|c|}
\hline Specimen & Locality & $\begin{array}{c}\text { Body + } \\
\text { tail length }\end{array}$ & $\begin{array}{l}\text { Head } \\
\text { width }\end{array}$ & $\begin{array}{c}\text { Body }+ \\
\text { tail annuli }\end{array}$ & Segments & Pores \\
\hline & Panamá & & & & & \\
\hline MZUSP 2101 & Panamá City & $295+x$ & 10 & $200+x$ & 46 & 8 \\
\hline MCZ 18924 & Gatun & $280+41$ & - & $195+27$ & 44 & 8 \\
\hline MCZ 18925 & Monte Lirio & $315+x$ & - & $200+x$ & 44 & 8 \\
\hline MCZ 22070 & Barro Colorado & $315+46$ & - & $197+24$ & 44 & 8 \\
\hline MCZ 24003 & Frijoles & $240+x$ & - & $200+x$ & 46 & 8 \\
\hline MCZ 24004 & Monte Lirio & $285+42$ & - & $196+23$ & 48 & 8 \\
\hline MCZ 37106 & Chagres River & $330+x$ & - & $202+x$ & 46 & 8 \\
\hline MCZ 37874 & Panamá City & $240+36$ & - & $195+24$ & 44 & 8 \\
\hline USNM 37859 & Canal Zone & $305+x$ & - & $201+x$ & 48 & 8 \\
\hline \multirow[t]{2}{*}{ USNM 38399} & Bohio & $350+52$ & - & $198+24$ & 48 & 8 \\
\hline & Colombia & & & & & \\
\hline MZUSP 57566 & Villavicencio & $328+x$ & 12 & $201+x$ & 50 & 8 \\
\hline AMNH 18237 & Caño Las Animas & $315+47$ & - & $192+25$ & 48 & 8 \\
\hline AMNH 27495 & Honda & $285+45$ & - & $201+25$ & 46 & 8 \\
\hline AMNH 27496 & Muzo & $310+45$ & - & $196+24$ & 48 & 7 \\
\hline AMNH 37439 & San Pedro & $285+40$ & - & $201+24$ & 46 & 6 \\
\hline AMNH 37440 & Medellin & $280+x$ & - & $196+x$ & 40 & 6 \\
\hline AMNH 37441 & , & $115+19$ & - & $195+25$ & 48 & 7 \\
\hline AMNH 37455 & Honda & $315+50$ & - & $205+26$ & 50 & 8 \\
\hline AMNH 62137 & Villavicencio & $440+x$ & - & $206+x$ & 50 & 8 \\
\hline BM 714 & Peña Lisa & $325+45$ & - & $202+24$ & 46 & 7 \\
\hline CM 30583 & Villavicencio & $235+38$ & - & $208+26$ & 48 & 8 \\
\hline MCZ 17647 & Paime & $290+45$ & - & $196+24$ & 42 & $\mathrm{x}$ \\
\hline MCZ 25052 & Rio Frio & $320+50$ & - & $199+25$ & 42 & 7 \\
\hline CM 27575 & Barrancabermeja & $225+35$ & - & $200+27$ & 42 & 8 \\
\hline MCZ 29683 & Andagoya & $405+58$ & - & $194+24$ & 42 & 6 \\
\hline MCZ 48959 & Leticia & $340+x$ & - & $214+x$ & 42 & 8 \\
\hline MCZ 48960 &, & $250+40$ & - & $221+26$ & 50 & 10 \\
\hline MCZ 42189 & Muzo & $265+33$ & - & $190+23$ & 42 & 6 \\
\hline MCZ 46437 &, & $250+34$ & - & $197+24$ & 42 & 6 \\
\hline MCZ 48961 & Leticia & $255+39$ & - & $207+25$ & 48 & 8 \\
\hline SU 8272 & Villavicencio & $400+55$ & - & $207+25$ & 52 & 9 \\
\hline \multirow[t]{2}{*}{ SU 8273} & , & $190+30$ & - & $199+25$ & 50 & 8 \\
\hline & Venezuela & & & & & \\
\hline MNH 69728 & Caripito & $175+25$ & - & $206+28$ & 46 & 6 \\
\hline MNH 69729 & , & $260+40$ & - & $209+27$ & 48 & 6 \\
\hline MCZ 49049 & Riecito & $260+39$ & - & $200+26$ & 50 & 8 \\
\hline
\end{tabular}


APPENDIX ( continuation )

\begin{tabular}{|c|c|c|c|c|c|c|}
\hline Specimen & Locality & $\begin{array}{c}\text { Body + } \\
\text { tail length }\end{array}$ & $\begin{array}{l}\text { Head } \\
\text { width }\end{array}$ & $\begin{array}{c}\text { Body }+ \\
\text { tail annuli }\end{array}$ & Segments & Pores \\
\hline & Trinidad & & & & & \\
\hline AMNH 6968 & Caparu & $260+42$ & - & $206+26$ & 46 & 8 \\
\hline AMNH 64440 & Tucker Valley & $265+40$ & - & $211+26$ & 46 & 8 \\
\hline AMNH 64462 & " & $215+30$ & - & $205+24$ & 42 & 8 \\
\hline AMNH 64462 A & , & $250+38$ & - & $210+25$ & 44 & 7 \\
\hline AMNH 64462 B &, & $210+29$ & - & $212+25$ & 42 & 6 \\
\hline AMNH $64462 \mathrm{C}$ & , & $195+25$ & - & $203+24$ & 46 & 6 \\
\hline AMNH 64523 & , & $250+x$ & - & $204+x$ & 42 & 7 \\
\hline AMNH $64523 \mathrm{~A}$ & , & $200+26$ & - & $209+27$ & 40 & 6 \\
\hline AMNH 64523 B & , & $235+36$ & - & $204+27$ & 42 & 6 \\
\hline BM 746 & - & $270+36$ & - & $204+27$ & 44 & 6 \\
\hline BM 749 & - & $293+45$ & - & $207-25$ & 44 & 7 \\
\hline CM 49910 & Brackfield & $240+37$ & - & $207+27$ & 44 & 8 \\
\hline CM 49912 & San Rafael & $245+39$ & - & $206+24$ & 44 & 8 \\
\hline CM 49912 A &, & $280+42$ & - & $206+26$ & 46 & 8 \\
\hline MCZ 10137 & Toco & $310+x$ & - & $205+x$ & 44 & 6 \\
\hline USNM $5751 \mathrm{~A}$ & - & $262+41$ & - & $202+25$ & 46 & 6 \\
\hline \multirow[t]{2}{*}{ USNM 5751 B } & - & $210+26$ & - & $205+26$ & 50 & 8 \\
\hline & Guyana & & & & & \\
\hline MZUSP 2000 & Kalacoon & $250+39$ & 8 & $205+26$ & 44 & 9 \\
\hline AMNH 1085 & Kaieteur Falls & $195+29$ & - & $199+25$ & 44 & 9 \\
\hline AMNH 7295 & Georgetown & $305+39$ & - & $207+24$ & 46 & 9 \\
\hline AMNH 17688 & , & $230+31$ & - & $208+25$ & 46 & 8 \\
\hline AMNH 17689 &, & $420+55$ & - & $213+24$ & 42 & 8 \\
\hline AMNH 25088 & Kamakusa & $205+x$ & - & $204+x$ & 40 & 8 \\
\hline AMNH 60907 & Marudi River & $230+32$ & - & $218+29$ & 46 & 8 \\
\hline BM 743 & Nappi, Kanuku Mts. & $265+40$ & - & $202+26$ & 48 & 10 \\
\hline BM 747 & Maccasseema & $180+x$ & - & $205+x$ & 50 & 10 \\
\hline \multirow[t]{2}{*}{ BM 748} & , & $235+35$ & - & $207+24$ & 50 & 8 \\
\hline & Suriname & & & & & \\
\hline MZUSP 2001 & Paramaribo & $145+22$ & 6 & $205+25$ & 48 & 8 \\
\hline MZUSP 9678 & Christiaankondre & $130+19$ & 6 & $192+26$ & $\mathrm{x}$ & 8 \\
\hline AMNH 8134 & Paramaribo & $240+36$ & - & $207+26$ & 46 & 9 \\
\hline AMNH 8135 &, & $285+x$ & - & $206+x$ & 52 & 8 \\
\hline AMNH 8649 &, & $215+x$ & - & $196+x$ & 48 & 10 \\
\hline AMNH 8650 & , & $275+39$ & - & $206+25$ & 50 & 8 \\
\hline AMNH 8678 &, & $135+21$ & - & $199+27$ & 46 & 8 \\
\hline MCZ 15719 & - & $350+51$ & - & $216+25$ & 46 & 8 \\
\hline USNM 6118 & - & $370+x$ & - & $205+x$ & 52 & 8 \\
\hline \multirow[t]{2}{*}{ USNM 58739} & - & $225+38$ & - & $203+27$ & 54 & 9 \\
\hline & French Guiana & & & & & \\
\hline CAS 14546 & St. Laurent du Maroni & $270+x$ & - & $211+x$ & 56 & 10 \\
\hline
\end{tabular}


APPENDIX ( continuation )

\begin{tabular}{|c|c|c|c|c|c|c|}
\hline Specimen & Locality & $\begin{array}{l}\text { Body + } \\
\text { tail length }\end{array}$ & $\begin{array}{l}\text { Head } \\
\text { width }\end{array}$ & $\begin{array}{c}\text { Body }+ \\
\text { tail annuli }\end{array}$ & Segments & Pores \\
\hline & Brasil: Roraima & & & & & \\
\hline MZUSP 49351 & Cachoeira Cujubim & $305+41$ & 11 & $198+23$ & 48 & $\mathrm{x}$ \\
\hline MZUSP 62841 & Vila Pacaraima & $315+50$ & 10 & $201+25$ & 50 & 9 \\
\hline MZUSP 62842 & , & $320+56$ & 13 & $199+26$ & 52 & 9 \\
\hline MZUSP 64961 &, & $360+54$ & 15 & $197+24$ & 50 & 8 \\
\hline MZUSP 69629 & Apiaú & $264+41$ & 10 & $198+24$ & 50 & $\mathrm{x}$ \\
\hline MZUSP 69630 & Maloca Mangueira & $280+x$ & 12 & $191+25$ & 50 & 8 \\
\hline MZUSP 70266 & Rio Barauana/BR-210 & $250+38$ & 9 & $187+23$ & $\mathrm{x}$ & 7 \\
\hline MZUSP 73760 & Ilha de Maracá & $255+42$ & 9 & $185+25$ & 50 & 7 \\
\hline MZUSP 78112 & Tepequém & $275+44$ & 10 & $183+24$ & 50 & 8 \\
\hline \multirow[t]{2}{*}{ MZUSP 79301} & Ilha de Maracá & $257+x$ & 9 & $201+x$ & 48 & 8 \\
\hline & Brasil: Amazonas & & & & & \\
\hline IB 673 & Manaus & $260+33$ & - & $212+25$ & 48 & 8 \\
\hline IB 674 &, & $240+30$ & - & $214+26$ & 48 & 8 \\
\hline MZUSP 1927 &, & $290+40$ & - & $219+26$ & 50 & 9 \\
\hline MZUSP 7664 & Tabatinga & $210+x$ & 8 & $208+x$ & 48 & 9 \\
\hline MZUSP 10914 & Manaus & $227+32$ & 9 & $213+23$ & 46 & 8 \\
\hline MZUSP 16928 & Itapiranga & $247+33$ & 9 & $224+24$ & 48 & 8 \\
\hline MZUSP 26012 & Manaus & $445+67$ & 8 & $219+25$ & 46 & 9 \\
\hline MZUSP 26013 & Manaus & $490+65$ & 17 & $206+22$ & 46 & 9 \\
\hline MZUSP 26014 &, & $251+x$ & 10 & $212+x$ & 46 & 9 \\
\hline MZUSP 26015 &, & $393+x$ & 16 & $212+x$ & 50 & 8 \\
\hline MZUSP 28238 & Humaitá & $285+43$ & 11 & $195+22$ & 48 & 8 \\
\hline MZUSP 38371 & Berurí & $178+51$ & 14 & $212+24$ & 48 & 8 \\
\hline MZUSP 51617 & Manaus & $301+41$ & 10 & $215+25$ & 48 & 8 \\
\hline MZUSP 52876 &, & $193+x$ & 7 & $213+x$ & 46 & 8 \\
\hline MZUSP 57559 &, & $275+x$ & 12 & $207+x$ & 44 & 8 \\
\hline MZUSP 57863 &, & $285+39$ & 10 & $214+24$ & 48 & 8 \\
\hline MZUSP 57864 &, & $210+x$ & 8 & - & 44 & 8 \\
\hline MZUSP 63643 & Balbina & $325+x$ & 13 & $210+x$ & 48 & 8 \\
\hline MZUSP 68641 &, & $342+43$ & 11 & $214+24$ & 48 & 8 \\
\hline MZUSP 68642 &, & $270+42$ & 10 & $214+26$ & 52 & 8 \\
\hline AMNH 37442 & Cucuí & $390+x$ & - & $208+x$ & 44 & 8 \\
\hline AMNH 37443 & , & $205+32$ & - & $214+29$ & 42 & 6 \\
\hline AMNH 37444 & Vista Alegre & $285+41$ & - & $202+25$ & 46 & 8 \\
\hline AMNH 64917 & Manaus & $152+x$ & - & $210+x$ & 46 & 8 \\
\hline AMNH 64918 & , & $170+21$ & - & $207+25$ & 44 & 8 \\
\hline AMNH 64919 &, & $280+37$ & - & $211+24$ & 48 & 8 \\
\hline MCZ 19540 &, & $230+29$ & - & $220+24$ & 48 & 8 \\
\hline MCZ 20663 &, & $270+39$ & - & $215+26$ & 50 & 8 \\
\hline MCZ 20664 &, & $330+40$ & - & $212+25$ & 48 & \\
\hline MCZ 20665 &, & $170+25$ & - & $220+28$ & 48 & 8 \\
\hline
\end{tabular}


APPENDIX ( continuation )

\begin{tabular}{|c|c|c|c|c|c|c|}
\hline Specimen & Locality & $\begin{array}{l}\text { Body + } \\
\text { tail length }\end{array}$ & $\begin{array}{l}\text { Head } \\
\text { width }\end{array}$ & $\begin{array}{c}\text { Body + } \\
\text { tail annuli }\end{array}$ & Segments & Pores \\
\hline & Brasil: Pará & & & & & \\
\hline MZUSP 3364 & Jacareacanga & $295+38$ & 13 & $198+22$ & 48 & 9 \\
\hline MZUSP 4714 & Tomé Açu & $225+30$ & 10 & $197+19$ & 48 & 8 \\
\hline MZUSP 4715 & Tomé Açu & $275+34$ & 12 & $202+20$ & 48 & 8 \\
\hline MZUSP 4716 &, & $280+32$ & 11 & $196+20$ & 50 & 8 \\
\hline MZUSP 6822 & Belém & - & - & $206+x$ & 48 & $\mathrm{x}$ \\
\hline MZUSP 6823 &, & - & - & $214+22$ & 46 & 8 \\
\hline MZUSP 6824 & , & $322+x$ & 12 & $208+x$ & 46 & 8 \\
\hline MZUSP 7653 & BR-010 km 93 & $342+x$ & 12 & $208+21$ & 48 & 8 \\
\hline MZUSP 8518 & Belém & $322+44$ & 12 & $207+22$ & 48 & 8 \\
\hline MZUSP 12337 & Canindé & $275+37$ & 11 & $208+23$ & 50 & 8 \\
\hline MZUSP 12356 & Oriximiná & $230+23$ & 9 & $198+22$ & 44 & 8 \\
\hline MZUSP 12357 & , & $206+27$ & 8 & $191+22$ & 42 & 8 \\
\hline MZUSP 13855 & , & $174+21$ & 7 & $196+23$ & 44 & 8 \\
\hline MZUSP 17436 &, & $280+x$ & 11 & $192+21$ & 46 & 9 \\
\hline MZUSP 36497 &, & $220+27$ & 8 & $191+20$ & 44 & 8 \\
\hline MZUSP 36498 &, & $252+29$ & 9 & $195+21$ & 48 & 8 \\
\hline MZUSP 77476 & , & $300+x$ & 11 & $196+x$ & 44 & 8 \\
\hline MZUSP 77823 & , & $252+x$ & 9 & $199+x$ & 46 & 8 \\
\hline \multirow[t]{2}{*}{ MZUSP 78409} & Serra Kukoinhokren & $410+x$ & 12 & $208+x$ & 46 & 8 \\
\hline & Brasil: Maranhão & & & & & \\
\hline \multirow[t]{2}{*}{ MZUSP 14439} & Açailândia & $335+50$ & 12 & $205+23$ & 56 & 7 \\
\hline & Brasil: Acre & & & & & \\
\hline MZUSP 5384 & Tarauacá & $292+47$ & 10 & $202+23$ & 40 & 8 \\
\hline \multirow[t]{2}{*}{ MZUSP 53456} & Porto Walter & $385+x$ & 17 & $198+x$ & 40 & 8 \\
\hline & Brasil: Rondonia & & & & & \\
\hline MZUSP 64736 & Santa Barbara & $207+30$ & 8 & $189+23$ & 44 & 8 \\
\hline MZUSP 64738 & RO-399 km 5 & $320+x$ & 12 & $205+24$ & 46 & 6 \\
\hline MZUSP 64763 & Alto Paraíso & $317+x$ & 11 & $199+x$ & 46 & 8 \\
\hline MZUSP 64908 & RO-399 km 1 & $255+34$ & 9 & $204+24$ & 40 & 8 \\
\hline MZUSP 64909 & RO-399 km 1 & $248+x$ & 10 & $202+x$ & 44 & 7 \\
\hline MZUSP 64910 & RO-399 km 1 & $275+40$ & 11 & $196+23$ & 46 & 8 \\
\hline MZUSP 66219 & Cachoeira Nazaré & $150+20$ & 6 & $185+24$ & 46 & 7 \\
\hline MZUSP 64923 & Santa Barbara & $265+x$ & 9 & $195+23$ & 46 & 8 \\
\hline \multirow[t]{2}{*}{ MZUSP 66348} & Cachoeira Nazaré & $245+34$ & 10 & $184+24$ & 44 & 8 \\
\hline & Brasil: Mato Grosso & & & & & \\
\hline MZUSP 81603 & Aripuanã & $370+x$ & 16 & $198+25$ & 46 & - \\
\hline MZUSP 82547 & , & $288+40$ & 12 & $204+24$ & 46 & 8 \\
\hline MZUSP 82798 & , & $341+48$ & 11 & $198+24$ & 44 & 9 \\
\hline MZUSP 82799 & , & $385+52$ & 14 & $195+24$ & 46 & 10 \\
\hline MZUSP 82800 & , & $310+x$ & 12 & $206+x$ & 52 & - \\
\hline MZUSP 82805 &, & $370+x$ & 14 & $301+25$ & 46 & 8 \\
\hline
\end{tabular}


APPENDIX ( continuation )

\begin{tabular}{|c|c|c|c|c|c|c|}
\hline Specimen & Locality & $\begin{array}{l}\text { Body }+ \\
\text { tail length }\end{array}$ & $\begin{array}{l}\text { Head } \\
\text { width }\end{array}$ & $\begin{array}{c}\text { Body }+ \\
\text { tail annuli }\end{array}$ & Segments & Pores \\
\hline & Brasil: Goiás & & & & & \\
\hline MZUSP 80223 & Piracanjuba & $294+39$ & 10 & $180+23$ & 52 & 8 \\
\hline MZUSP 83397 & Serra da Mesa & $345+50$ & 13 & $192+24$ & 52 & 8 \\
\hline MZUSP 83398 &, & $300+41$ & 11 & $199+25$ & 50 & 9 \\
\hline MZUSP 83399 & , & $324+x$ & 12 & $193+x$ & 52 & 8 \\
\hline MZUSP 83400 &, & $332+45$ & 14 & $202+26$ & 52 & 9 \\
\hline MZUSP 83401 & , & $284+40$ & 11 & $192+26$ & 52 & 8 \\
\hline MZUSP 83402 &, & $315=45$ & 13 & $191+25$ & 52 & 9 \\
\hline MZUSP 83403 & , & $338+x$ & 14 & $196+x$ & 48 & 8 \\
\hline MZUSP 83404 &, & $333+x$ & 13 & $196+x$ & 48 & 6 \\
\hline MZUSP 83405 &, & $335+x$ & 14 & $198+x$ & 52 & 8 \\
\hline MZUSP 83406 & , & $339+x$ & 15 & $194+x$ & 50 & 8 \\
\hline MZUSP 87694 & , & $353+55$ & 15 & $195+24$ & 50 & 8 \\
\hline \multirow[t]{2}{*}{ MZUSP 87695} &, & $330+47$ & 15 & $189+27$ & 52 & 8 \\
\hline & Brasil: Bahia & & & & & \\
\hline AMNH 1091 & Santa Maria Eterna & $335+51$ & - & $206+24$ & 52 & 9 \\
\hline AMNH 1092 &, & $280+49$ & - & $197+28$ & 52 & 10 \\
\hline \multirow[t]{2}{*}{ AMNH 1093} &, & $250+x$ & - & $202+x$ & 50 & 8 \\
\hline & Ecuador & & & & & \\
\hline MZUSP 3404 & Canelos & $130+20$ & 6 & $197+27$ & 40 & 7 \\
\hline MZUSP 6425 & $\begin{array}{l}\text { Santo Domingo de } \\
\text { los Colorados }\end{array}$ & $280+41$ & 10 & $196+22$ & 44 & 7 \\
\hline MZUSP 6426 & , & $235+42$ & 12 & $197+22$ & 46 & 7 \\
\hline MZUSP 6427 &, & $322+52$ & 12 & $193+23$ & 46 & 6 \\
\hline MZUSP 6428 & Canelos & $312+x$ & 11 & $198+x$ & 42 & 8 \\
\hline MZUSP 6429 & Loreto & $228+51$ & 12 & $202+26$ & 44 & 8 \\
\hline MZUSP 6430 & , & $310+55$ & 9 & $202+27$ & 44 & 8 \\
\hline MZUSP 6431 & Pichilingue & $339+50$ & 12 & $190+23$ & 44 & 7 \\
\hline AMNH 2285 & Riobamba & $340+x$ & - & $197+x$ & 44 & 8 \\
\hline AMNH 22090 & Bucay & $350+55$ & - & $198+25$ & 44 & 7 \\
\hline AMNH 23324 & Riobamba & $275+44$ & - & $204+26$ & 44 & 8 \\
\hline AMNH 23325 &, & $360+62$ & - & $203+29$ & 44 & 8 \\
\hline AMNH 23326 & , & $295+45$ & - & $202+26$ & 42 & 8 \\
\hline AMNH 28784 & Turula & $380+64$ & - & $202+27$ & 44 & 9 \\
\hline AMNH 28785 &, & $350+x$ & - & $200+x$ & 42 & 8 \\
\hline AMNH 37862 & Baños to Canelos & $250+x$ & - & $205+x$ & 44 & 9 \\
\hline AMNH 56593 & Rio Cenipa & $315+x$ & - & $196+x$ & 42 & 8 \\
\hline AMNH 56595 &, & $290+x$ & - & $209+x$ & 44 & 7 \\
\hline BM 741 & Guayaquil & $315+51$ & - & $200+28$ & 44 & 9 \\
\hline \multirow[t]{2}{*}{ BM 742} & Santo Domingo de & & & & & \\
\hline & los Colorados & $295+42$ & - & $193+23$ & 46 & 8 \\
\hline BM 745 & 50 km E Loja & $275+41$ & - & $199+29$ & 42 & 8 \\
\hline
\end{tabular}


APPENDIX ( continuation )

\begin{tabular}{|c|c|c|c|c|c|c|}
\hline Specimen & Locality & $\begin{array}{c}\text { Body }+ \\
\text { tail length }\end{array}$ & $\begin{array}{l}\text { Head } \\
\text { width }\end{array}$ & $\begin{array}{c}\text { Body }+ \\
\text { tail annuli }\end{array}$ & Segments & Pores \\
\hline & Ecuador (cont.) & & & & & \\
\hline MCZ 3572 & Rio Daule & $220+34$ & - & $196+27$ & 44 & 8 \\
\hline MCZ 7799 A & Riobamba & $345+50$ & - & $199+23$ & 44 & 8 \\
\hline MCZ 7799 B & , & $320+46$ & - & $205+25$ & 46 & 7 \\
\hline MCZ 37271 & Rio Pastaza & $370+x$ & - & $207+x$ & - & - \\
\hline \multirow[t]{2}{*}{ SU 8259} & Avila & $365+60$ & - & $200+26$ & 42 & 8 \\
\hline & Peru & & & & & \\
\hline AMNH 56224 & Iquitos & $250+x$ & - & $208+26$ & 44 & 8 \\
\hline AMNH 56310 & Pampa Hermosa & $365+62$ & - & $208+28$ & 44 & 8 \\
\hline AMNH 56588 & Iquitos & $450+75$ & - & $206+27$ & 44 & 8 \\
\hline AMNH 86589 &, & $280+47$ & - & $209+28$ & 44 & 8 \\
\hline AMNH 56590 & , & $270+46$ & - & $205+29$ & 44 & 8 \\
\hline AMNH 56592 & , & $330+x$ & - & $204+x$ & 42 & 8 \\
\hline AMNH 56594 & Contamana & $105+16$ & - & $210+26$ & 38 & 8 \\
\hline AMNH 56596 & Iquitos & $365+64$ & - & $206+29$ & 44 & 8 \\
\hline AMNH 56597 &, & $360+61$ & - & $211+30$ & 44 & 8 \\
\hline AMNH 56598 & , & $305+55$ & - & $209+29$ & 44 & 8 \\
\hline AMNH 56599 & , & $255+52$ & - & $210+29$ & 44 & 8 \\
\hline AMNH 56600 & , & $275+51$ & - & $210+30$ & 44 & 8 \\
\hline AMNH 56601 & Reforma & $315+56$ & - & $204+29$ & 44 & 8 \\
\hline AMNH 56602 & Iquitos & $300+50$ & - & $204+28$ & 42 & 8 \\
\hline AMNH 56603 &, & $245+39$ & - & $207+27$ & 44 & 8 \\
\hline AMNH 56605 & , & $340+57$ & - & $205+29$ & 44 & 8 \\
\hline AMNH 56606 & Roaboya & $275+42$ & - & $211+28$ & 42 & 7 \\
\hline AMNH 56607 & , & $275+45$ & - & $211+28$ & 42 & 7 \\
\hline AMNH 56608 & Requena & $205+35$ & - & $215+29$ & 42 & 8 \\
\hline AMNH 56609 & Contamana & $295+50$ & - & $208+29$ & 44 & 8 \\
\hline AMNH 56610 & Iquitos & $395+75$ & - & $208+29$ & 44 & 8 \\
\hline AMNH 56611 & Rio Cushabatay & $305+46$ & - & $211+27$ & 44 & 8 \\
\hline AMNH 56612 & Boca Santiago & $300+55$ & - & $205+28$ & 42 & 8 \\
\hline AMNH 56613 & Roaboya & $245+39$ & - & $212+26$ & 42 & 7 \\
\hline AMNH 56617 & Iquitos & $370+60$ & - & $206+29$ & 44 & 8 \\
\hline AMNH 56618 & , & $360+61$ & - & $210+30$ & 44 & 8 \\
\hline BM 703 & Rio San Gaban & $275+40$ & - & $207+27$ & 40 & 8 \\
\hline BM 704 & , & $335+73$ & - & $205+27$ & 42 & 7 \\
\hline BM 705 & Rio Cushabatay & $270+x$ & - & $210+x$ & 40 & 8 \\
\hline BM 740 & Rio San Gaban & $275+41$ & - & $207+27$ & 40 & 7 \\
\hline CM 45471 & Iquitos & $341+x$ & - & $213+x$ & 44 & 8 \\
\hline CM 45472 & , & $270+40$ & - & $208+26$ & 46 & 6 \\
\hline MCZ 45784 & Pucallpa & $325+48$ & - & $215+29$ & 38 & 8 \\
\hline
\end{tabular}




\section{GAZETTEER}

South American localities of Amphisbaena fuliginosa.

Latitudes South and longitudes West taken for granted.

The last number of each entry corresponds to Map 1.

The coordinates of rivers are, unless otherwise specified, those of the mouth.

Açailandia (Brasil, Maranhão) 0547, 4741, 49

Alto Paraíso (Brasil, Rondonia) 0937, 6327, 54

Andagoya (Colombia, Chocó) 0506 N, 7640, 5

Apiaú (Brasil, Roraima) 0240 N, 6115, 19

Aripuanã (Brasil, Mato Grosso) 1020, 5923, 5

Avila (Ecuador, Napo) 0038, 7725, 26

Balbina, UHE (Usina Hidroelétrica) (Brasil, Amazonas) 0153, 5928, 32

Baños (Ecuador, Pastaza) 0124, 7825, 27

Barauana, Rio, at Highway BR-210 (Brasil, Roraima) 0128 N, 6052, 22

Barrancabermeja (Colombia, Santander) 0703 N, 7352, 2

Belém (Brasil, Pará) 0126, 4829, 28

Berurí (Brasil, Amazonas) 0354, 6122, 41

Boca Santiago (Peru, Amazonas) 0427, 7738, 45

Bucay (Ecuador, Guayas) 0210, 7907, 33

Canelos (Ecuador, Pastaza) 0135, 7744, 29

Canindé, Rio Gurupí (Brasil, Pará) 0233, 4631, 37

Caripito (Venezuela, Monagas) 1007 N, 6305, 32

Cashiboya (Peru, Loreto) 0651, 7440, 50

Cenipa, Rio (Peru, Amazonas) 0439, 7810, 46

Charobamba (Bolivia, La Paz) 1437, 6844, 65

Christiaankondre (Suriname) 0543 N, 5401, 7

Contamana (Peru, Loreto) 0720, 7502, 51

Cucuí (Brasil, Amazonas) 0113 N, 6650, 23

Cujubim, Cachoeira do (falls), Rio Catrimani (Brasil, Roraima) 0145 N, 6217, 21

Cushabatay, Rio (Peru, Loreto) 0709, 7508, 51

Daule, Rio (Ecuador, Guayas), 0210, 7952, 18

Georgetown (Guyana) 0647 N, 5811, 3

Guayaquil (Ecuador, Guayas) 0210, 7952, 18

Honda (Colombia, Tolima) 0512 N, 7445, 10

Humaitá (Brasil, Amazonas) 0731, 6302, 62

Iquitos (Peru, Loreto) 0347, 7313, 40

Itapiranga (Brasil, Amazonas) 0244, 5801, 38

Jacareacanga (Brasil, Pará) 0615, 744, 63 


\section{GAZETTEER ( continuation )}

Latitudes South and longitudes West taken for granted.

The last number of each entry corresponds to Map 1.

The coordinates of rivers are, unless otherwise specified, those of the mouth.

Kaieteur Falls (Guyana) 0510 N, 5928, 11

Kalacoon (Guyana) 0623 N, 5838, 4

Kamakusa (Guyana) 0556 N, 5954, 6

km 1 Highway RO-399 (Brasil, Rondonia) 1244, 6016, 57

km 5 Highway RO-399 (Brasil, Rondonia) 1242, 6011, 57

km 93 Highway BR-010 (Brasil, Pará) 0212, 4734, 34

Kukoinhokren, Serra de (Brasil, Pará) 0750, 5155, 64

Las Animas, Caño (Colombia, Chocó) 0520 N, 7643, 5

Leticia (Colombia, Amazonas) 0409, 6957, 43

Loja (Ecuador, Loja) 0400, 7910, 42

Loreto (Ecuador, Napo) 0038, 7719, 11

Maccasseema (Guyana) 0715 N, 5843, 1

Manaus (Brasil, Amazonas) 0307, 6000, 39

Mangueira, Maloca (Indian village) (Brasil, Roraima) 0318, N, 6127, 18

Maracá, Ilha de, Rio Uraricoera (Brasil, Roraima) 0325 N, 6140, 16

Marudi River (Guyana) 0207 N, 5934, 20

Medellin (Colombia, Antioquia) 0615 N, 7536, 5

Mesa, Serra da (Brasil, Goiás) 1415, 4835, 56

Muzo (Colombia, Boyacá) 0532 N, 7406, 8

Nappi, Kanuku Mts. (Guyana) 0325 N, 5934, 17

Nazaré, Cachoeira de (falls), Rio Machado or Ji-Paraná (Brasil, Rondonia) 0945, 6155, 55

Oriximiná (Brasil, Pará) 0146, 5551, 31

Pacaraima, Vila (border-marker BV-8) (Brasil, Roraima) 0430 N, 6109, 12

Paime (Colombia, Cundinamarca) 0522 N, 7410, 9

Pampa Hermosa (Peru, Loreto) 0712, 7518, 51

Paramaribo (Suriname) 0505 N, 5510, 40

Pastaza, Rio (Ecuador, Pastaza) 0455, 7624, 47

Peña Lisa (Colombia, Chocó) 0506 N, 7637, 5

Pichilingue (Ecuador. Los Rios) 0106, 7928, 12

Piracanjuba (Brasil, Goiás) 1718, 4901, 62

Porto Walter (Brasil, Acre) 0816, 7244, 52

Pucallpa (Peru, Ucayali) 0823, 7433, 53

Reforma (Peru, Loreto) 0644, 7458, 50

Requena (Peru, Loreto) 0504, 7353, 48

Riecito (Venezuela, Falcón) 1055 N, 6844, 31

Riobamba (Ecuador, Chimborazo) 0140, 7839, 30 
Latitudes South and longitudes West taken for granted.

The last number of each entry corresponds to Map 1.

The coordinates of rivers are, unless otherwise specified, those of the mouth.

Rio Frio (locality) (Colombia, Magdalena) 1054 N, 7411, 1

Roaboya (Peru, Loreto) 0748, 7446, 51

Saint Laurent du Maroni (French Guiana) 0530 N, 5402, 42

San Gaban, Rio (Peru, Puno) 1325, 7018, 30

San Pedro (Colombia, Valle del Cauca) 0400 N, 7613, 14

Santa Barbara (Brasil, Rondonia) 0910, 6304, 54

Santa Maria Eterna (Brasil, Bahia) 1551, 3925, 59

Santo Domingo de los Colorados (Ecuador, Pichincha) 0015, 7929, 24

Sorata (Bolivia, La Paz) 1547, 6840, 66

Tabatinga (Brasil, Amazonas) 0414, 6955, 44

Tarauacá (Brasil, Acre) 0810, 7046, 60

Tepequém (Brasil, Roraima) 0345 N, 6145, 15

Tipuani (Bolivia, La Paz) 1533, 6800, 67

Tomé Açu (Brasil, Pará) 0224, 4809, 36

Turula, Rio Upano (Ecuador, Morona - Santiago) 0213, 7811, 35

Villavicencio (Colombia, Meta) 0409 N, 7337, 13

Vista Alegre, Rio Negro (Brasil, Amazonas) 0021, 6427, 25

Yungas (Bolivia, La Paz) 1610, 6730, 68

contrary to other formations (e.g. African) also called "savannas", and this makes untenable the adoption of a same name for both formations. Cerrado vegetation is highly characteristic, both physiognomically and taxonomically (Heringer et al. 1976); it includes several sub-types of cerrados, from open fields to dry forests, as well as gallery forests and forest enclaves of diverse types and extent. This is a very different, and much richer, scenario than the simplistic ones usually envisaged.

\section{ACKNOWLEDGMENTS}

I am indebted, for critical readings of the manuscript, to W.Ronald Heyer, C.W. Myers, Celso Morato de Carvalho, May Christine Modenesi and Jürgen Haffer - they do not uniformly agree with me on all matters. The photographs are the work of Maria Stela Murgel, the graphs that of Pablo R. Oñate. I owe the map to Lucio S. Shibazaki. The scannings were done at the MZUSP library by Maria da Conceição Bueno da Silva. To all, my thanks.

\section{RESUMO}

A diferenciação geográfica de Amphisbaena fuliginosa (Reptilia, Amphisbaenia, Amphisbaenidae) é estudada com base em 220 exemplares de 99 localidades definidas e 2 localidades genéricas. O padrão encontrado apoia a conclusão de Vanzolini (1951) de que são reconhecíveis subespécies, definidas pelo padrão de colorido e por 4 caracteres merísticos. Esse padrão de diferenciação resultaria de eventos paleoclimáticos Quaternários. Contribuições recentes sobre modelos de diferenciação no Quaternário da América tropical são brevemente discutidos.

Palavras-chave: sub-espécie, paleoclima, Amphisbaena, modelo e refúgios. 


\section{REFERENCES}

Aв'Saber AN. 1967. Domínios morfoclimáticos e províncias fitogeográficas do Brasil. Orientação (Dep Geogr Univ S. Paulo) 3: 45-48.

AB'SABER AN. 1971. A organização natural das paisagens inter e subtropicais brasileiras, p. 1-14 in MG FERRI, III Simpósio sobre o Cerrado.

AB'SABER AN. 1977. Os domínios morfoclimáticos na América do Sul. Primeira aproximação. Geomorfologia (Inst Geogr Univ S. Paulo) 52: 22p.

Aв’SABER AN. 1979. Os mecanismos de desintegração das paisagens tropicais no Pleistoceno. Interfacies (Univ Estadual Paulista S. José do Rio Preto) 4: 17p.

Aв'SABER AN. 1982. The paleoclimate and paleoecology of Brazilian Amazonia, p. 41-59 in GT Prance, ed., Biological diversification in the tropics.

AB'SABER AN. 1996a. Amazônia: do discurso à praxis. S. Paulo: Edusp. 320p.

Ab'Saber AN. 1996b. Paleoclima e paleoecologia da Amazônia brasileira, p. 49-66 in AN AB'SABER, Amazônia: do discurso à praxis (translation of Ab'Saber 1982).

Argollo J And Mourguiart P. 1995 (eds.). Climas cuaternarios en America del Sur. La Paz: ORSTOM (Proyecto PICG-281).

BoKERMANN WCA. 1957. Atualização do itinerário da viagem do Príncipe de Wied ao Brasil (1815-1817). Arq Zool S. Paulo 10: 209-251.

Brasil, Escritório de Meteorologia, Ministério dA Agricultura. 1968. Normais climatológicas. Rio de Janeiro. 3 vols.

Bush MB. 1994. Amazon speciation: a necessarily complex model. J Biogeogr 21: 5-17.

Campbell KE JR and Frailey CD. 1985. Paleontological investigations in southeastern Peru. Nat Geogr Soc Res Rept 1977 Projects: 189-199.

Carson HL. 1987. The genetic system, the deme and the origin of species. Ann Rev Genet 21: 405-423.

Colinvaux PA. 1993. Pleistocene biogeography and diversity in tropical forests of South America, p. 473499 in P GoldBlatT, ed., Biological relationships between Africa and South America

Colinvaux PA. 1996. Quaternary environmental history and forest diversity in the Neotropics, 359-405 in JACKSON JBC, Budd AF AND CoATES AG. (eds), Evolution and environment in tropical America.

Colinvaux PA. 1998. A new vicariance model for Amazonian endemics. Global Ecol Biogeogr Lett 7: 9596.

Colinvaux PA, Oliveira PE, Moreno JE, Miller MC AND BusH MB. 1996. A long pollen record from lowland Amazonia: forest and cooling in glacial climates. Science 274: 85-88.

Colinvaux PA, Irion G, Räsänen ME, Bush MB And Nunes De Mello JAS. 2001. A paradigm to be discarded: geological and paleontological data falsify the Haffer \& Prance refuge hypothesis of Amazonian speciation. Amazoniana 16: 609-646.

Dixon WJ AND Massey JR FJ. 1983. Introduction to statistical analysis. Fourth Edition. New York etc: McGraw Hill. xv + 678p.

DobZhansky T. 1937. Genetics and the origin of species. New York: Columbia University Press (Columbia Biological Series 11), xvi + 364p.

Dumont JF, Lamotte S and Kahn F. 1990. Wetland and upland forest ecosystems in Peruvian Amazonia: plant species diversity in the light of some geological and botanical evidence. Forest Ecol Manag 33/34: 125-139.

Duncan DB. 1957. Multiple range tests for correlated and heteroscedastic means. Biometrics 13: 164-176.

FERRI MG. 1971 (coord.). III Simpósio sobre o cerrado. S. Paulo: Edgard Blücher; Edusp. (6) + 239p.

FERRI MG. 1976 (coord.). IV Simpósio sobre o cerrado. S. Paulo: Edusp; Belo Horizonte: Itatiaia. 405p.

Fittkau EJ, Illies J, Klinge H, Schwabe GH AND Sioli H. 1969 (eds.). Biogeography and ecology in South America. The Hague: W. Junk (Monographiae Biologicae 19). 2 vols.

FJelds Å J, Lambin E and Mertens B. 1999. Correlation between endemism and local ecoclimatic instability documented by comparing Andean bird distribution and remotely sensed land surface data. Ecography 22: 63-78.

Frailey CD. 1986. Late Miocene and Holocene mammals, exclusive of the Notoungulata, of the Rio Acre region, western Amazonia. Los Angeles Co. Mus Contrib Sci 374: (ii) $+46 p$. 
Goldblatt P. 1993. Biological relationships between Africa and South America. New Haven: Yale University Press. 630p.

Gould SJ. 1965. Is uniformitarianism necessary? Amer J Sci 263: 223-228.

Gray JE. 1844. Catalogue of the tortoises, crocodiles, and amphisbaenians, in the collection of the British Museum. London: Trustees of the British Museum. viii $+72 p$.

HAFFer J. 1969. Speciation in Amazonian forest birds. Science 165: 131-137.

HAfFer J. 1993. Time's cycle and time's arrow in the history of Amazonia. Biogeographica 69: 15-45.

Haffer J And Prance GT. 2001. Climatic forcing of evolution in Amazonia during the Cenozoic: on the refuge theory of biotic differentiation. Amazoniana 16: $579-607$

Heringer EP, Barroso GM, Rizzo JA and Rizzini CT. 1976. A flora do cerrado, p. 211-231 in FERRI MG, coord. IV Simpósio sobre o cerrado.

Hooghiemstra H. 2001. The continuing debate on the history of the Amazonian rain forest. Amazoniana 16: 653-656.

Hooghiemstra H And van Der Hammen T. 1998. Neogene and Quaternary development of the Neotropical rain forest: the forest refugia hypothesis, and a literature overview. Earth Sci Rev 44: 147-183.

HuXley J. 1940 (ed.). The new systematics. Oxford: Clarendon Press. viii $+583 p$.

IrIONdo M ANd LAtrubesse EM. 1994. A probable scenario for a dry climate in central Amazonia during the Late Quaternary. Quatern Int 21: 121-128.

JACKson JBC, Budd AF And CoATEs AG. 1998 (eds.). Evolution and environment in tropical America. Chicago and London: University of Chicago Press. ix $+425 \mathrm{p}$.

KrAMER CY. 1956. Extension of multiple range tests to group means with unequal numbers of replications. Biometrics 12: 307-310.

Kronberg BI and Benchimol RE. 1993. Climatic changes reflected in geochemistry and stratigraphy of Acre Basin sediments (western Amazonia). Quatern S America Antarctic Peninsula 8: 191-199.

LABOURIAU LG. 1966. Revisão da situação da Ecologia
Vegetal nos cerrados. An Acad Bras Cienc 38 (Supl.): 5-38.

Latrubesse EM. 1996. La Formación Solimões en el estado de Acre, Amazonia, Brasil, p. 68-72 in LATrubesse EM, coord., Paleo e neoclimas da Amazonia sul-ocidental. (Southwestern Amazonia paleoand neoclimates. Paleo y neoclimas de Amazonia sudocidental). Conferencia de campo. Rio Branco: Univ. Federal Acre, Lab. Geomorfologia e Sedimentologia. $89 \mathrm{p}$.

Latrubesse EM and Franzinelli E. 1995. Cambios climaticos en Amazonia durante el Pleistoceno tardio - Holoceno, p. 77-93 in Argollo J AND Mourguiart P., eds. Climas cuaternarios en America del Sur.

LAtrubesse EM and Ramonell CG. 1994. A climatic model for southwestern Amazonia in late Glacial times. Quatern Int 21: 163-169.

Latrubesse EM And Rancy A. 1998. The Late Quaternary of the Upper Juruá River, southwestern Amazonia, Brazil: geology and vertebrate paleontology. Quatern S America Antarctic Peninsula 11: 27-46.

LAURENTI JN. 1768. Specimen medicus exhigens synopsin reptilium. Vienna: J. Thoma. (6) +214+(2)p. (Facsimile edition 1966, A. Asher).

LEDRU MP. 1993. Late Quaternary environmental and climatic change in Central Brazil. Quatern Res 39: 90-98.

Linnaeus C. 1749. Amoenitates academicae, seu dissertartiones variae... Lugduni Batavorum (Leiden); Cornelius Haak. (1) +610+9p. (Surinamensia Grilliana, resp. P. Sundius, p. 489-519).

LinnaEus C. 1758. Systema naturae per regna tria naturae, secundum classes, ordines, genera, species cum characteribus, differentiis, synonymis, locis. Tomus I. Editio Decima, reformata. Stockholm: Laur. Salvius. $824 \mathrm{p}$.

LÖNNBERG E. 1896. Linnean type specimens of birds, reptiles, batrachians and fishes in the Zoological $\mathrm{Mu}$ seum of the R. University in Uppsala. Bih. t. K. Svenska Vet.-Akad. Handl. 22

LÖNNBERG E. 1926. Einige Bemerkungen über den Einfluss der Klimaschwankungen auf die Afrikanische Vogelwelt. J Ornith 74 (2): 259-273 (4) art. 1: 45p.

Markgraf V. 1993. Climatic history of Central and 
South America since 18,000 yr. B.P. Comparison of pollen records and model simulations, p. 357-385 in Wright HE et AL. Global climates since the Last Glacial maximum.

Maxson L and Heyer WR. 1988. Molecular systematics of the frog genus Leptodactylus (Amphibia: Leptodactylidae). Fieldiana Zool (N. S.) 41: 1-13.

MAYr E. 1942. Systematics and the origin of species from the viewpoint of a zoologist. New York: Columbia University Press (Columbia Biological Series 13). xiv $+334 p$.

Myers CW and Böhme W. 1996. On the type specimens of two Colombian poison frogs described by A.A. Berthold and their bearing on the locality "Provinz Popayan". Amer Mus Novit 3185: 20p.

Patton JL, Silva MNF and Malcolm JR. 2000. Mammals of the Rio Juruá and the ecological and evolutionary diversification of Amazonia. Bull Amer Mus Nat Hist. 244: 1-306.

Paula Couto C. 1944. Notícia preliminar sobre um novo Toxodonte do Cenozóico do Território do Acre. Bol Mus Nac Rio de Janeiro Geol (N.S.) 3: 1-4.

Prance GT. 1982 (ed.). Biological diversification in the tropics. New York: Columbia University Press. xvi $+714 \mathrm{p}$.

Projeto Radambrasil. 1981. Levantamento de recursos naturais. Vol. 25. Folha SD. 22 Goiás. Rio de Janeiro: Departamento da Produção Mineral. 636p.

RANCY A. 1993. A paleofauna da Amazônia indica áreas de paisagem com pouca cobertura vegetal. Ciência Hoje 16 (93) (Supl. "Paleoclimas da Amazônia"): 48-51.

Räsänen M, Salo JS and Kalliola RJ. 1987. Fluvial perturbance in the western Amazon basin: regulation by long-term sub-Andean tectonics. Science 238: 1398-1401.

RHODES C. 1963. On Amphisbaena fuliginosa Linné from Bolivia. Herpetologica 19 (3): 175-178.

Salati E, Marques J and Molion LCB. 1978. Orígem e distribuição de chuvas na Amazônia. Interciencia 3 (4): 200-206.

Sant'Anna-Filho MJ, Trindade A and Marques GM. 1996. Mamíferos fósseis do Quaternário de Rondonia, p. 26-36 in Latrubesse EM, org, Paleo e neoclimas da Amazônia sul-ocidental.
Schwabe GH. 1969. Towards an ecological characterization of the South American continent, 113-136 in Fittkau EJ, Illies J, Klinge H, Schwabe GH and Sioli H., eds. Biogeography and ecology in South America.

Stehli FG and Webb SD. 1985. The great American biotic interchange. New York and London: Plenum Press. xvii $+532 p$.

Tamayo F. 1972. Los llanos de Venezuela. Caracas: Monte Avila. 2 vols.

VAN DER HAMMEN T. 2001. Ice-age tropical South America: What was it really? Amazoniana (3-4): 647-652.

van Der Hammen T AND Hooghiemstra H. 2001. Neogene and Quaternary history of vegetation, climate and plant diversity in Amazonia. Quatern Sci Rev. 19: 725-752.

VANZOLINI PE. 1951. Contributions to the knowledge of the Brasilian lizards of the family Amphisbaenidae Gray, 1825. 6. On the geographical distribution and differentiation of Amphisbaena fuliginosa Linné. Bull Mus Comp Zool. 106: 1-67.

Vanzolini PE. 1991. Two new small species of Amphisbaena from the fossil dune field of the middle Rio São Francisco, state of Bahia, Brasil (Reptilia, Amphisbaenia). Papéis Avulsos Zool. S. Paulo 37: 259-276.

VAnZolini PE. 1993. Paleoclimas e especiação de animais na América do Sul tropical. Estudos Avançados (Univ. S. Paulo) 6 (15) (“1992”): 41-65.

VANZOLInI PE. 1993a. Métodos estatísticos elementares em sistemática zoológica. S. Paulo: Hucitec. 130p.

VANZOLINI PE. 1994. Brasilian reptiles in open and closed formations: evolutionary implications. An Acad Bras Cienc. 66 (Supl. 1): 173-176.

VANZOLINI PE. 1997. The silvestrii species-group of Amphisbaena, with the description of two new Brasilian species (Reptilia: Amphisbaenia). Papéis Avulsos Zool. S. Paulo, 40 (3): 65-85.

Vanzolini PE. 1999. On Anops (Reptilia: Amphisbaenia: Amphisbaenidae). Papéis Avulsos Zool. S. Paulo 41(1): 1-37.

Vanzolini PE and Heyer WR. 1985. The American herpetofauna and the interchange, p. 475-487 in Stehli FG and Webb SD., eds., The great American interchange. 
Vanzolini PE and Williams EE. 1970. South American anoles: the geographic differentiation and evolution of the Anolis chrysolepis species group (Sauria, Iguanidae). Arq Zool S. Paulo, 19 (1-4): 1-298.

Vanzolini PE and Williams EE. 1981. The vanishing refuge: a mechanism for ecogeographic speciation. Papéis Avulsos Zool. S. Paulo 34 (23): 251-256.

WAibel L. 1948. Vegetation and land-use in the Planalto Central of Brazil. Geogr Rev 38 (4): 529-554.

Webb SD and Rancy A. 1996. Late Cenozoic evolution of the Neotropical mammal fauna, 335-358 in JACKSON JBC, BUdD AF AND CoATES AG., eds., Evolution and environment in tropical America.
Whitmore TC and Prance GT. 1987. Biogeography and Quaternary history in tropical America. Oxford: Clarendon Press (Oxford Monographs on Biogeography). viii $+214 p$.

Wied-Neuwied Maximilian Prinz zU. 1820-1821. Reise nach Brasilien in den Jahren 1815 bis 1817. Frankfurt a.M.: Brönner HL. 2 vols.

Wright He, Kutzbach JE, Webb III T, Ruddiman WF, Street-Perrott FA and Bartlein PJ. 1993 (eds.). Global climates since the Last Glacial maximum. Minneapolis and London: University of Minnesota Press. viii $+569 p$.

ZAR JH. 1999. Biostatistical analysis. Fourth edition. Upper Saddle River, New Jersey: Prentice Hall. xi + $661+212+11+20+23 p$. 